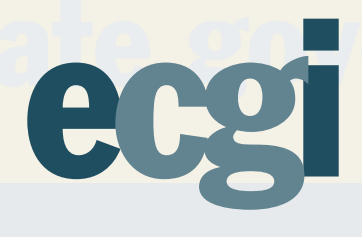

\title{
Corporate Technologies and the Tech Nirvana Fallacy
}

Law Working Paper N 457/2019

March 2020

\section{Luca Enriques}

University of Oxford and ECGI

Dirk A. Zetzsche

University of Luxembourg and Heinrich-HeineUniversity Düsseldorf
(C) Luca Enriques and Dirk A. Zetzsche 2020. All rights reserved. Short sections of text, not to exceed two paragraphs, may be quoted without explicit permission provided that full credit, including $(\subset$ notice, is given to the source.

This paper can be downloaded without charge from: http://ssrn.com/abstract_id=3392321

https://ecgi.global/content/working-papers 


\title{
ECGI Working Paper Series in Law
}

\section{Corporate Technologies}

\author{
and the \\ Tech Nirvana Fallacy
}

\author{
Working Paper $N^{\circ} 457 / 2019$ \\ March 2020 \\ Luca Enriques \\ Dirk A. Zetzsche
}

The authors are thankful for comments from, and conversations on the topic with, Mark Adams, Nikita Aggarwal, John Armour, Douglas Arner, Daniel Awrey, William Birdthistle, Christopher Bruner, Ross Buckley, Michael Burstein, Isabelle Corbisier, Horst Eidenmüller, Eilís Ferran, Holger Fleischer, Merritt Fox, Joshua Getzler, Ron Gilson, Matthew Jennejohn, Sergio Gramitto Ricci, Jeff Gordon, Andrew Green, David Hiez, Herwig Hoffmann, Edward Iacobucci, David Kershaw, Joshua Mitts, Ulrich Noack, Muna Ndulo, Saule Omarova, Edmund-Philipp Schuster, Gerald Spindler, Eric Talley, Christiane Wendehorst, Arnold Weinrib, Sam Weinstein, Aaron Wright, Charles Yablon, Albert Yoon, as well as participants to presentations and workshops at Bocconi University, Cardozo Law School, Columbia Law School, Consob, Cornell Law School, the Center for International Governance Research, Harvard Law School, the Ibero-American Institute for Law and Finance, the London School of Economics, the University of Luxembourg, Monash University, the National University of Singapore, the University of Chicago-Kent, University College London, the University of Oxford, the Sorbonne, the University of Sydney Law School, the University of Toronto, the Technical University of Munich and Yale Law School. Moritz Spenke and Pamela Cela provided valuable research assistance.

(C) Luca Enriques and Dirk A. Zetzsche 2020. All rights reserved. Short sections of text, not to exceed two paragraphs, may be quoted without explicit permission provided that full credit, including (C) notice, is given to the source. 


\begin{abstract}
This article introduces the term Corporate Technologies ("CorpTech") to refer to the use of distributed ledgers, smart contracts, Big Data analytics, Al and machine learning in the corporate context and analyzes the impact of CorpTech on the future of corporate boards. We focus on the tech manifestation of agency problems within corporations and identify-after considering possible market, governance, and regulatory solutions-elements of a governance framework for the CorpTech age. In particular, we take on a prediction often found in the literature, namely that CorpTech has the potential to solve all corporate governance problems for good and make boards of directors redundant. We argue that this claim is based on what we call the tech nirvana fallacy, the tendency of comparing supposedly perfect machines with failure-prone humans. The inherent features of technology and corporate governance reveal that even well-programmed CorpTech leaves the core issue of corporate governance-conflicts of interest among the relevant corporate stakeholders-untouched. In the Corptech age, the key question becomes: "is the human being that selects or controls the firm's tech conflicted?" If so, CorpTech itself will be tainted. In fact, the problems arising from the transition to a CorpTech-dominated governance environment may, in the short-term, make things even worse: insufficient understanding of the promise and perils of CorpTech and over-confidence therein may even aggravate agency problems within firms.
\end{abstract}

Keywords: Algorithms, Artificial Intelligence, Blockchain, Board of Directors, Compliance, Corporate Governance, CorpTech, Distributed Ledgers, RegTech, Risk Management, Smart Contracts

JEL Classifications: D23, G38, K22, L22, M15, O16

\title{
Luca Enriques
}

Allen \& Overy Professor of Corporate Law

University of Oxford, Faculty of Law

St.Cross Building, St. Cross Road

Oxford, OX1 3UL, United Kingdom

phone: +44 1865289751

e-mail: luca.enriques@law.ox.ac.uk

Dirk A. Zetzsche*

ADA Chair in Financial Law

University of Luxembourg, Faculty of Law, Economics and Finance

4 , rue Alphonse Weicker

L-2721 Luxembourg, Luxembourg

phone: +3524666445092

e-mail: dirk.zetzsche@uni.lu

${ }^{*}$ Corresponding Author 


\title{
CORPORATE TECHNOLOGIES AND THE TECH NIRVANA FALLACY
}

\author{
Luca Enriques \& Dirk A. Zetzsche*
}

Final Draft - March 2020

\begin{abstract}
This article introduces the term Corporate Technologies ("CorpTech") to refer to the use of distributed ledgers, smart contracts, Big Data analytics, AI and machine learning in the corporate context and analyzes the impact of CorpTech on the future of corporate boards. We focus on the tech manifestation of agency problems within corporations and identify — after considering possible market, governance, and regulatory solutions-elements of a governance framework for the CorpTech age.

In particular, we take on a prediction often found in the literature, namely that CorpTech has the potential to solve all corporate governance problems for good and make boards of directors redundant. We argue that this claim is based on what we call the tech nirvana fallacy, the tendency of comparing supposedly perfect machines with failure-prone humans. The inherent features of technology and corporate governance reveal that even wellprogrammed CorpTech leaves the core issue of corporate governance-conflicts of interest among the relevant corporate stakeholders-untouched. In the Corptech age, the key question becomes: "is the human being that selects or controls the firm's tech conflicted?" If so, CorpTech itself will be tainted. In fact, the problems arising from the transition to a CorpTech-dominated governance environment may, in the short-term, make things even worse: insufficient understanding of the promise and perils of CorpTech and overconfidence therein may even aggravate agency problems within firms.
\end{abstract}

${ }^{*}$ Luca Enriques is Professor of Corporate Law at the University of Oxford Faculty of Law and Fellow of the European Corporate Governance Institute (ECGI).

Dirk Zetzsche is ADA Chair in Financial Law (Inclusive Finance) at the University of Luxembourg Faculty of Law, Economics and Finance, Director of the Centre for Business and Corporate Law, Heinrich-Heine-University, Düsseldorf, Germany, and an Academic Member of ECGI.

The authors are thankful for comments from, and conversations on the topic with, Mark Adams, Nikita Aggarwal, John Armour, Douglas Arner, Daniel Awrey, William Birdthistle, Christopher Bruner, Ross Buckley, Michael Burstein, Isabelle Corbisier, Horst Eidenmüller, Eilís Ferran, Holger Fleischer, Merritt Fox, Joshua Getzler, Ron Gilson, Matthew Jennejohn, Sergio Gramitto Ricci, Jeff Gordon, Andrew Green, David Hiez, Herwig Hoffmann, Edward Iacobucci, David Kershaw, Joshua Mitts, Ulrich Noack, Muna Ndulo, Saule Omarova, Edmund-Philipp Schuster, Gerald Spindler, Eric Talley, Christiane Wendehorst, Arnold Weinrib, Sam Weinstein, Aaron Wright, Charles Yablon, Albert Yoon, as well as participants to presentations and workshops at Bocconi University, Cardozo Law School, Columbia Law School, Consob, Cornell Law School, the Center for International Governance Research, Harvard Law School, the Ibero-American Institute for Law and Finance, the London School of Economics, the University of Luxembourg, Monash University, the National University of Singapore, the University of Chicago-Kent, University College London, the University of Oxford, the Sorbonne, the University of Sydney Law School, the University of Toronto, the Technical University of Munich and Yale Law School. Moritz Spenke and Pamela Cela provided valuable research assistance. Usual disclaimers apply. 


\section{TABLE OF CONTENTS}

INTRODUCTION ...........................................................................................3

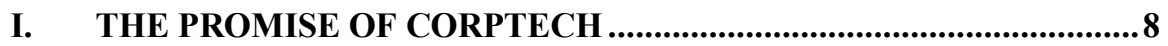

A. DisTRIBUTED LEDGERS, BLOCKCHAINS AND SMART CONTRACTS ..............8

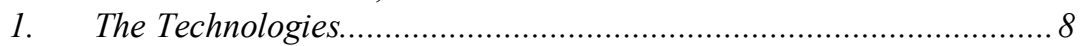

2. DLT-based CorpTech Solutions .................................................. 10

B. Big Data, ARTificial INTELLIGENCE AND MACHINE LEARNING ........... 12

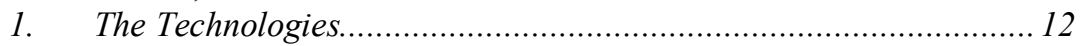

2. AI-based CorpTech................................................................. 13

II. CORPTECH'S IMPACT: THE END OF THE BOARD AS WE

KNOW IT? 15

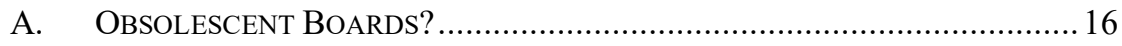

1. Real-time Accounting and "Full Transparency" ............................ 16

2. $\quad$ More Direct Shareholder Influence ……………........................... 17

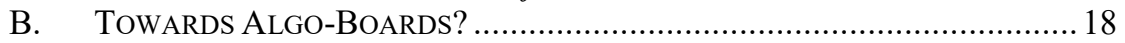

III. THE DEMISE OF THE BOARD: A TECH NIRVANA FALLACY ... 19

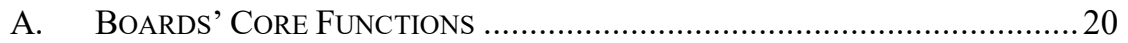

1. The Monitoring Board …….................................................... 20

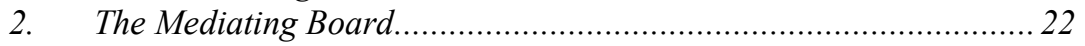

B. Automation of Monitoring as the Solution? ................................23

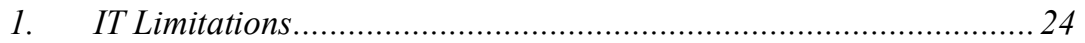

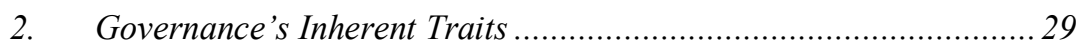

C. THE BOARD DISINTERMEDIATION HYPOTHESIS...................................... 33

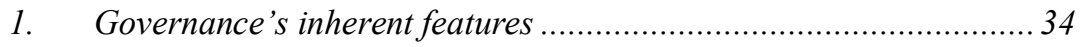

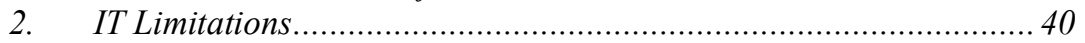

D. INTERMEDIATE RESULTS: UTOPIA RECONSIDERED ............................... 41

IV. A GOVERNANCE FRAMEWORK FOR THE CORPTECH AGE.... 42

A. PRODUCT MARKET COMPETITION? .......................................................... 43

B. Best Practices: ExPanding the Board Committees' Remit to

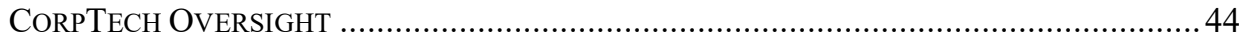

C. The CASE Against CoRpTeCh Regulation.........................................4

D. ENhANCING CORPTECH-RELATEd DisClosures ...................................49

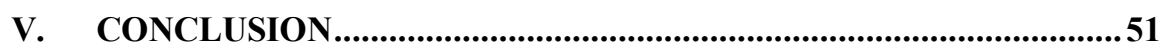




\section{INTRODUCTION}

In one of the largest financial scandals to date, WellsFargo, the U.S. largest bank by number of employees, admitted to the opening of some 3.5 million deposit and credit card accounts without consumer knowledge, leading to fabricated quarterly earnings and a boost to the Wells Fargo stock price. The scandal resulted in a dozen of U.S. Senate and House Committee hearings, various U.S. and state regulators' inquiries, penalties and fines, with total costs exceeding $\$ 4.5$ billion to date, an unprecendeted "asset cap" imposed on Wells Fargo in early 2018 for "widespread consumer abuses," a fundamental revamp of WellsFargo's compensation, compliance and riskmanagement system, forfeiture of CEO pay, and the departure of several executives, including three CEOs within three years. ${ }^{1}$ The WellsFargo scandal is the latest reminder of how, almost 90 years after Berle \& Means's seminal book The Modern Corporation and Private Property, ${ }^{2}$ the mechanisms to ensure that agents within corporations perform their tasks and duties in line with the long-term interests of their shareholders (and other stakeholders, as the case may $\mathrm{be}^{3}$ ), rather than pursuing their immediate self-

1 See Press Release, Office of the Attorney General Commonwealth of Pennsylvania: Attorney General Shapiro Announces \$575 Million 50-State Settlement with Wells Fargo Bank for Opening Unauthorized Accounts and Charging Consumers for Unnecessary Auto Insurance, Mortgage Fees (Dec. 28, 2018), https://www.attorneygeneral.gov/takingaction/press-releases/attorney-general-shapiro-announces-575-million-50-state-settlementwith-wells-fargo-bank-for-opening-unauthorized-accounts-and-charging-consumers-forunnecessary-auto-insurance-mortgage-fees/ (detailing misconduct sanctioned as well as penalties, fines and settlement costs until end of 2018 of \$ 3 billion); Matt Egan, Wells Fargo Takes \$1.6 Billion Hit Linked to Fake-Account Scandal, CNN Business, Oct. 15, 2019, https://edition.cnn.com/2019/10/15/investing/wells-fargo-earnings-scandal/index.html (detailing additional inquiries, sanctions and penalties through Oct. 25, 2019).

2 Adolf A. Berle \& Gardiner Means, The Modern Corporation and Private PROPERTY (1932).

3 While the prevailing U.S. corporate governance view has long expected management to focus on wealth creation for shareholders only, things have changed in recent years, as shown, for instance, by the letter of Larry Fink, Chairman and Chief Executive Officer of the world's largest asset manager BlackRock, to the CEOs of US listed companies. See BlackRock, Larry Fink's 2018 Letter to CEOs - A Sense of Purpose (2018), https://www.blackrock.com/corporate/investor-relations/2018-larry-fink-ceo-letter (stating that "[t]o prosper over time, every company must not only deliver financial performance, but also show how it makes a positive contribution to society. Companies must benefit all of their stakeholders, including shareholders, employees, customers, and the communities in which they operate."). Multi-stakeholderism may be understood as the new mainstream. Yet, we will mainly keep our focus here on shareholders as a key constituency with a wellestablished role in companies' internal governance, given their (hitherto exclusive) power to appoint directors. 
interest, are far from fail-proof. ${ }^{4}$

If laws, best practices, ethical standards and market pressures have so far been unable to tackle this core corporate governance challenge, perhaps technology can. Would algorithms and machines, with their more powerful, disinterested, and unbiased information-processing capacity, be better at monitoring corporate agents?

Breath-taking advancements in information technology (IT) are characterizing the $21^{\text {st }}$ century, from big data analytics, ${ }^{5}$ artificial intelligence (AI) and machine learning ${ }^{6}$ to distributed ledger technology, including blockchains, ${ }^{7}$ and smart contracts. ${ }^{8}$ Many expect these technologies, which we collectively refer to as "CorpTech," to prompt fundamental changes in the law $^{9}$ as well as in corporate governance. ${ }^{10}$

CorpTech comprises all solutions relating to corporate governance broadly defined, including tools to set executive compensation, identify candidates for top positions within the organization, facilitate investor relations, corporate voting and the internal workings of the board of directors, manage risk, and enhance compliance functions. ${ }^{11}$ However, the term does not extend to operations software products such as those used for sales, R\&D

$4 \quad$ See generally Michael C. Jensen \& William H. Meckling, Theory of the Firm: Managerial Behavior, Agency Costs and Ownership Structure, 3 J. FIN. ECON. 305, 308 (1976) (arguing that moral hazard is a firm's main determinant of agency costs).

$5 \quad$ See e.g. Solon Barocas \& Andrew D. Selbst, Big Data's Disparate Impact 104 CAL. L. REV. 671, 677-693 (2016) (describing big data analytics).

$6 \quad$ See e.g. Harry Surden, Machine Learning and Law, 89 U. WASH. L. REV. 87,10210 (2014) (discussing progress on AI research and how it may affect the practice of the law).

$7 \quad$ See e.g. Dirk A. Zetzsche, Ross P. Buckley \& Douglas W. Arner, The Distributed Liability of Distributed Ledgers: Legal Risks of Blockchain, 2018 U. ILL. L. REV. 1361, 1370-74 (introducing the concept of distributed ledgers); PRIMAVERA DE FILIPPI \& AARON Wright, BLOCKCHAIN AND THE LAW - THE RULE OF CODE 13-57 (2018) (describing blockchains).

$8 \quad$ See e.g. Jeremy M. Sklaroff, Smart Contracts and the Cost of Inflexibility, 166 U. PA. L. REV. 263, 273-78 (2017) (analyzing features of smart contracts); Kevin Werbach \& Nicolas Cornell, Contracts Ex Machina, 67 DuKE L.J. 313, 367-81 (2017) (describing smart contracts).

$9 \quad$ See e.g. Chris Brummer, Disruptive Technology and Securities Regulation, 84 FORDHAM L. REV. 977 (2015) (arguing that securities regulation must be adapted to FinTech).

$10 \quad$ See infra Part II.

11 CorpTech differs from RegTech: the latter is the use of technology in the context of risk management, compliance, reporting and regulatory oversight; it thus overlaps with CorpTech only in part, i.e. in its component relating to risk management oversight and compliance. See e.g. Douglas W. Arner, Janos Barberis \& Ross P. Buckley, FinTech, RegTech and the Reconceptualization of Financial Regulation, 37 Nw. J. INT'L L. \& Bus. 371, 377-84 (2017). 
and production management. ${ }^{12}$

With regard to corporate governance, scholars have speculated as to the possible use of the new technologies to improve discrete corporate practices, such as shareholder identification, ${ }^{13}$ shareholder proposals, proxy fights, ${ }^{14}$ electronic voting, virtual shareholder meetings, ${ }^{15}$ digitalized compliance and risk management, ${ }^{16}$ as well as to the impact of these new technologies on the corporate purpose. ${ }^{17}$ Attention has also been focused on an arguably fringe phenomenon, algorithmic entities, or "self-driving corporations," whereby humans relinquish control over the corporation to an algorithm. ${ }^{18}$ Others have delved into discrete legal questions arising from the use of AI to assist, if not replace, boards in their decision-making functions, ${ }^{19}$

12 Importantly, though, the boundaries between CorpTech and operations technology will necessarily be hazy, since effective CorpTech requires integration into the rest of a firm's information systems. For instance, in the WellsFargo case (see supra note 1 and accompanying text), the fraud originated in the bank's retail sales department. Effective CorpTech oversight would have required access to fraud indicators available only on the operations level.

13 See e.g. George S. Geis, Traceable Shares and Corporate Law, 113 Nw. U.L. REV. 227, 238-53 (2018). See also Delaware State Senate, 149th General Assembly, Senate Bill No. 69: An act to Amend Title 8 of the Delaware Code Relating to the General Corporation Law (explicitly allowing for the use of the blockchain to maintain corporate share registries). $14 \quad$ See Geis, supra note 13, at 272-73.

15 See Michael D. Goldman \& Eileen M. Filliben, Corporate Governance: Current Trends and Likely Developments for the Twenty-First Century, 25 DEL. J. CORP. L., 683, 689 \& 695 (2000); Anne Lafarre \& Christoph Van der Elst, Blockchain Technology for Corporate Governance and Shareholder Activism (European Corporate Governance Institute (ECGI) - Law Working Paper No. 390/2018); Christoph Van der Elst \& Anne Lafarre, Blockchain and Smart Contracting for the Shareholder Community, 20 EUR. BuS. ORG. L. REV. 111 (2019); Carla Reyes, Nizan G. Packin \& Benjamin Edwards, Distributed Governance, 59 WM. \& MARY L. REV. ONLINE 1 (2016).

16 See Kenneth A. Bamberger, Technologies of Compliance: Risk and Regulation in a Digital Age, 88 TEX. L. REV. 669, 722-38 (2010) (discussing the governance implications of digitalized compliance and risk management).

17 See Christopher Bruner, Distributed Ledgers, Artificial Intelligence, and the Purpose of the Corporation 19 (2019) (unpublished manuscript, on file with authors) (arguing that the core issues of corporate purpose remain unchanged by technology).

18 See Shawn J. Bayern, Of Bitcoins, Independently Wealthy Software, and the ZeroMember LLC, 108 Nw. U.L. REV. 1485, 1495-1500 (2014) (discussing algorithmic entities, corporations with no members, no directors and running merely on software); Lynn M. LoPucki, Algorithmic Entities, 95 WASH. U.L. REV. 887 (2018) (discussing the perils of algorithmic entities). See also John Armour \& Horst Eidenmüller, Self-Driving Corporations, HARV. BUS. L. REV. _ (forthcoming 2020) (manuscript available as ECGI Law Working Paper No. $475 / 2019$ (2019), at 25-33) (developing a conceptual framework for self-driving corporations and highlighting regulatory challenges).

19 See Max Bankewitz, Carl Åberg \& Christine Teuchert, Digitalization and Boards of Directors: A New Era of Corporate Governance?, 5 Bus. \& MGMT. RES. 58 (2016) 
and on the related question of whether algorithms may themselves (and should be allowed to) serve as board members. ${ }^{20}$

Some scholars though, and among them NYU professor David Yermack, have speculated as to how new technologies will reshape corporate governance more broadly. These scholars, whom we refer to as "tech proponents," share the view that technology will fundamentally change existing corporate governance paradigms and may even eradicate longstanding corporate governance problems. ${ }^{21}$ From their perspective, technology is the solution to the ultimate challenge in corporate governance, namely how to deal with (human) corporate agents' inherent imperfections, including their dogged self-interestedness and pervasive biases. ${ }^{22}$ Multiple corporate scandals (from Enron and WorldCom in the early $2000 \mathrm{~s}^{23}$ up until WellsFargo ${ }^{24}$ ), as well as the most severe financial crisis in the last century, ${ }^{25}$

(predicting that under the influence of digitalization boards will become virtual networks of people with diminished needs to monitor management).

20 See Sergio A. Gramitto Ricci, Artificial Agents in Corporate Boardrooms, 105 CORNELL L. REV. (forthcoming 2020) (manuscript on file with authors, at 24-34) (discussing $\mathrm{AI}$ as a board member under Delaware law and arguing that the Roman law for slaves may offer a model for its legal treatment); Martin Petrin, Corporate Management in the Age of AI, Colum. Bus. L. REV. _ (forthcoming 2020) (manuscript available as UCL Working Paper No. 3/2019, at 34-35) (predicting the advent of AI directors). This is of course part of the broader debate on humans' race against the machines. See generally ANDREW MCAFEE \& ERIK BRYNJOLFSSON, RACE AgAinst THE MACHINE (2011) (detailing the replacement of human labor by computers); Carl B. Frey \& Michael A. Osborne, The Future of Employment: How Susceptible Are Jobs to Computerisation?, 114 TeChnOlOGICAL ForeCASTInG \& SoC. CHANGE 254 (2017) (making predictions about the same).

21 See infra Part II.

22 See e.g. with specific reference to the corporate board setting, Antony Page, Unconscious Bias and the Limits of Director Independence, 2009 U. ILL. L. REV. 238, 24883.

23. In the Enron and WorldCom cases executives had not only misled their boards of directors and audit committees on high-risk accounting practices, but also successfully pressured their audit firm (soon-to-be defunct Arthur Andersen) to ignore the issues. See e.g. John C. Coffee Jr., What Caused Enron - A Capsule Social and Economic History of the 1990s, 89 Cornell L. Rev. 269, especially at 302 (2004); Curtis J. Milhaupt \& Katharina Pistor, LaW and CAPitalism: What Corporate Crisis Reveal About Legal Systems AND ECONOMic DeVelopment ARound the World 47-67 (2008) (discussing the Enron scandal).

$24 \quad$ See supra note 1 and accompanying text.

25 In the run-up to the global financial crisis, inappropriately incentivized investment bankers issued subprime "toxic" securitized mortgage assets, and rating agencies analysts were prone to issuing over-optimistic ratings thereon, which finally found their way into banks' and institutional investors' portfolios around the globe. See e.g. ROBERT J. SHILLER, The Subprime Solution: How Today's Global Financial Crisis Happened, And WhAT To Do ABOUT IT (2008) (providing an account of the crisis). Some commentators and international organizations attribute the global financial crisis of 2007 partially or primarily 
bear testimony of the disastrous consequences that the wrong corporate governance arrangements can have on shareholders and other stakeholders alike. If automated solutions become available that will finally keep corporate agents on a tight leash without unduly constraining their ability to create value, then we might be on the verge of a new era in which corporations, liberated from the pernicious effects of agency costs, can become even more formidable engines for growth and prosperity.

Tempting as it may be to set up perfect machines against failure-prone humans (what we call the tech nirvana fallacy ${ }^{26}$ ), a better understanding of both the available technology and the enduring role of humans in its design and deployment justifies a soberer assessment of technology's impact on corporate governance. In providing this assessment, our article is the first to provide the conceptual groundwork for a sound governance framework in an age where humans and machines interact.

In order to develop this framework, this article spells out the limitations of the new technologies as applied to corporate governance and the inherent features of corporate governance itself. It argues that the conflicts of interest and information asymmetries that have always characterized corporate governance seep into the code of CorpTech applications. The allocation of power over the selection of particular CorpTech solutions will determine the degree of control that any constituency (directors, management, shareholders, and other stakeholders) can exert over the firm. We also dismiss as similarly unrealistic the idea that shareholders (let alone other stakeholders) may disintermediate boards and monitor management directly themselves. Boards will continue to perform their core monitoring and mediation functions for the predictable future. Yet, we acknowledge that CorpTech, and hence adaption of corporate governance to CorpTech, is ever more important for the functioning of corporate boards.

to weaknesses in corporate governance arrangements and humans' skewed incentives. See e.g., OECD, Corporate Governance and the Financial Crisis: Key Finding And MAIN MESSAGES 41 (2009) ("The financial crisis has also pointed in a large number of cases to boards of financial companies that were ineffective and certainly not capable of objective, independent judgment."); Brian R. Cheffins, The Corporate Governance Movement, Banks and the Financial Crisis, 16 THEORETICAL INQUIRIES L. 1, 31-41 (2015) (observing that the persistence of imperial CEOs at U.S. banks "plausibly contributed to the onset of the financial crisis").

26 The nirvana fallacy refers to the misconception, common among legal scholars, of comparing the real world, with its market imperfections, with a failproof, perfectly regulated one. See e.g. Daniel R. Fischel, The Corporate Governance Movement, 35 VAND. L. REV. 1259,1272 (1982). The fallacy, but not the term "nirvana fallacy" itself, was first highlighted by the economist Harold Demsetz (Harold Demsetz, Information and Efficiency: Another Viewpoint, 12 J.L. \& ECON. 1, 1, 2 (1969) (introducing the "nirvana approach," described as above, as being susceptible to three common fallacies: the grass is always greener fallacy, the fallacy of the free lunch and the people could be different fallacy). 
On this basis, we lay out the pillars of a governance framework designed to steer the cooperation between humans and machines in the CorpTech age: boards should extend their monitoring functions by extending the remit of existing committees or by establishing tech committees in charge of CorpTech oversight. We also make the case for mandatory disclosure of CorpTech-related corporate governance arrangements.

We conclude that, while CorpTech may speed up procedures, and governance practices may include a greater degree of code deployment and data analytics, barring technological breakthroughs that eventually displace human judgment in corporate decision-making processes entirely, CorpTech will not make the corporate boards' core functions obsolete. So long as humans yield influence over the firm, the question of who decides what code is deployed and what data is processed will be key, and traditional corporate governance mechanisms will retain their core function of curbing agency problems within the firm.

The article proceeds as follows. Part I provides the technical context of our analysis. Part II presents the tech proponents' view that CorpTech solutions will supplant the monitoring board, while shareholder direct involvement will make the mediating board obsolete. Part III counters these claims, arguing that conflicts of interest are bound to remain at the heart of corporate governance. Who selects the CorpTech for the firm will determine whose interests CorpTech products will cater to. Part IV develops the elements of a CorpTech-dominated governance framework designed to address corporate governance challenges in the CorpTech age, Part V concludes.

\section{THE PROMISE OF CORPTECH}

This part briefly describes the newly available technologies that are affecting, or are likely to affect, the functions typically associated with corporate boards: distributed ledgers, the blockchain and smart contracts (section I.A); and, next, big data analytics, artificial intelligence and machine learning (section I.B).

\section{A. Distributed Ledgers, Blockchains and Smart Contracts}

1. The Technologies

A distributed ledger is "a database that is consensually shared and 
synchronized across networks spread across multiple sites, institutions or geographies, allowing a transaction to have [multiple private or] public 'witnesses'." ${ }^{27}$ The sharing of data results in a sequential database distributed across a network of servers all of which together function as a ledger. ${ }^{28}$ Distributed ledgers are characterized by an absence of, or minimal, central administration and no centralized data storage. They are, hence, "distributed," in the sense that the authorization for the recording of a given piece of information results from the software-driven interaction of multiple participants. Coupled with cryptographic solutions, such features (decentralization and distribution across a network of computers) curtail the risk of data manipulation, thereby solving the problem of trusting third parties, and specifically data storage service providers. ${ }^{29}$

The modus operandi of distributed ledgers is best understood by looking at their counterpart, the concentrated ledger. Let us assume that a centralized register administered by a single entity contains all the relevant data. That arrangement entails a number of risks. First, if the hardware where the register is "located" is destroyed, the information content, as well as the authority to ascertain that they are correct, are lost. Second, disloyal employees of the database administrator or an unfaithful administrator may manipulate the information content of the register. Third, a cyber-attack may result in manipulations and data losses. ${ }^{30}$

Distributed ledgers address these problems by raising the barrier for manipulation. The underlying technology requires consensus of many data storage points ("nodes"). If there are $n$ nodes (instead of one concentrated ledger) and $e$ describes the effort necessary to break into any single server,

27 WORLd ECONOMIC FORUM, INNOVATION-Driven CYBER-Risk to CUSTOMER Data IN Financial Services - White PAPER 5 (Figure 2) (2017), http://www3.weforum.org/docs/WEF_Cyber_Risk_to_Customer_Data.pdf.

28 See David Mills et al., Distributed Ledger Technology in Payments, Clearing, and Settlement 10-11 (Wash.: Bd. of Governors of the Fed. Reserve Sys., Finance and Economics Discussion Series 2016-095, 2016), https://doi.org/10.17016/FEDS.2016.095.

29 See Michèle Fink, Blockchain Regulation and Governance in Europe 1214 (2019). See also Sinclair Davidson, Primavera De Filippi, \& Jason Potts, Blockchains and the economic institutions of capitalism, 14 J. INST. ECON. 639 (2018) (arguing that blockchain technology is a new governance institution that competes with other economic institutions of capitalism, namely firms, markets, networks, and even governments); DE FILIPPI \& WRIGHT, supra note 7, at 55, 136-40 (arguing that widespread deployment of blockchain will lead to tech-based business practices that could prompt a loss in importance of centralized authorities, such as government, and urging a more active regulatory approach).

30 Any server can be manipulated with sufficient computing power and time (even if no other weakness in an encryption system is known to the attackers). See generally JEANPhilippe Aumasson, Serious Cryptography: A Practical Introduction to Modern ENCRYPTION 10-18, 40-48 (2017). 
all other conditions being equal (safety per server etc.), the effort necessary to manipulate all the linked servers will be $n \times e$ rather than $1 \times e$.

Distributed ledgers are usually paired with a blockchain protocol. ${ }^{31}$ Blockchain refers to the storage of all data parts as data bundles (the 'blocks') in a strict time-related series which links each block, through a time stamp, to the previous and subsequent blocks. The blockchain renders data corruption even harder, because a successful cyberattack would require simultaneously corrupting not just one set of data, but multiple data sets (i.e. the whole blockchain) as well as the time stamps simultaneously.

Distributed ledgers have provided fertile ground for the application of another innovation that may solve the problem of trust in human interactions: smart contracts. ${ }^{32}$ While neither smart, nor contracts, they are in fact selfexecuting software protocols that reflect the terms of an agreement between two parties. ${ }^{33}$ The conditions of the agreement are directly written into lines of code. Smart contracts permit the execution of transactions between disparate, anonymous parties without the need for an external enforcement mechanism (such as a court, an arbitrator, or a central clearing facility). They render transactions traceable, transparent, and irreversible. Since processes driven by smart contracts are often saved on distributed ledgers, we refer to these three technologies collectively as distributed ledger technologies (DLTs).

\section{DLT-based CorpTech Solutions}

DLTs are already altering, and will further alter, the way companies are directed and controlled. ${ }^{34}$ Notable experiments center around shareholder voting. For instance, Fidelity Investments, the world's fourth-largest asset manager, has developed SOCOACT, a blockchain-based voting system

31 See e.g. DE FILIPPI \& WRIGHT, supra note 7, at 33-58; Zetzsche, Buckley \& Arner, supra note 7 , at 1372 .

$32 \quad$ See supra note 8 for references.

33 See e.g. Anthony J. Casey \& Anthony Niblett, Self-Driving Contracts, 43 J. CoRP. L. 1, 5 (2017); Joshua Fairfield, Smart Contracts, Bitcoin Bots, and Consumer Protection, 71 Wash. \& LeE L. ReV. Online 35, 36 (2014); Karen E.C. Levy, Book-Smart, Not StreetSmart: Blockchain-Based Smart Contracts and The Social Workings of Law, 3 ENGAGING SCI., TECH. \& SOC'Y 1 (2017); Werbach \& Cornell, supra note 32, at 313.

34 See e.g. Assaf Hamdani, Niron Hashai, Eugene Kandel \& Yishay Yafeh, Technological Progress and the Future of the Corporation, 6 J. BRITISH ACAD. 215, 225 (2018) (arguing that, because DLTs reduce fraud and enhance trust, they have the potential to displace "powerful intermediaries."). 
designed to authenticate voters and ensure fair (corporate) voting processes. ${ }^{35}$ Computershare, a provider of share-registers-as-a-service, tabulation services and technical vote processing at shareholder meetings, has teamed-up with SETL, a provider of blockchain-based central securities depositary services, in an effort to establish the world's first blockchain-based immutable register of securities ownership. ${ }^{36}$ Following a trial with J.P. Morgan, Northern Trust, and Banco Santander, ${ }^{37}$ Broadridge, whose business includes managing the information flows between the institutional investor holding the shares and the issuer, ${ }^{38}$ obtained a patent for utilizing the Ethereum blockchain for proxy voting and share repurchases. ${ }^{39}$

Similarly, Northern Trust, one of the largest and oldest U.S. banks, has developed a blockchain solution with technology giant IBM for board meetings. The package includes two smart contracts that record meeting attendance by collecting biometric information from the various devices an attendee may carry and collects all pertinent information about the meeting, such as the action points and associated dates. It also converts all such information into meeting minutes, following a standardized format. A third smart contract will post the minutes of the meeting and associated documents in a pre-determined repository. ${ }^{40}$ That will allow meeting attendance and individual contributions to be instantaneously stored in a predetermined and well-searchable format.

Developments such as these have stimulated the tech proponents' optimism that DLT applications could also tackle a particularly thorny area of corporate governance: executive compensation. Specifically, smart contracts could be used to make compensation arrangements harder to alter in opportunistic ways further down the road, a phenomenon known as

35 See U.S. Patent Office, Patent Application Publication, Pub. No. US 2017/0046689 A1, Pub. Date: Feb. 16, 2017, at (57) https://www.lens.org/lens/patent/135-803-859-153-697/fulltext.

36 See Press Release, SETL, Computershare and SETL demonstrate Australia's first working blockchain solution (Apr. 28, 2016, updated Nov. 7, 2017), https:/www.setl.io/blog/computershare-and-setl-demonstrate-australia-s-first-workingblockchain-solution.

37 Jim Manning, Major Finance Companies Complete Blockchain-Based Proxy Vote Solution (Apr. 11, 2017), https://www.ethnews.com/major-finance-companies-completeblockchain-based-proxy-vote-solution.

38 On custodian chains see e.g. Marcel Kahan \& Edward B. Rock, The Hanging Chads of Corporate Voting. 96 GEO. L.J. 1227, 1236-48 (2008).

39 Jordan Danielle, Broadridge Patents Blockchain Solution for Proxy Voting and Repurchase Agreements (May 10, 2018) https://www.ethnews.com/broadridge-patentsblockchain-solution-for-proxy-voting-and-repurchase-agreements.

$40 \quad$ Christine Kim, Northern Trust Wins Patent for Storing Meeting Minutes on a Blockchain (Jun. 6, 2018) https:/www.coindesk.com/northern-trust-wins-patent-storingmeeting-minutes-blockchain. 
"backdating." ${ }^{41}$ More generally, it has been suggested that, instead of relying on (potentially) conflicted compensation consultants and their own (often self-serving) biases, ${ }^{42}$ boards could use smart contracts to determine compensation structures and bonuses. ${ }^{43}$ To the best of our knowledge, though, there is no publicly available evidence that any such product has yet been developed.

\section{B. Big Data, Artificial Intelligence and Machine Learning}

\section{The Technologies}

Big data analytics refers to the collection and processing of data sets that are either too large or too complex for traditional data processing applications to handle. ${ }^{44}$ Big data applications look at the bulk of data points and apply advanced data analytics methods to detect unexpected correlations, test expected correlations for causation, or determine the probability of a predefined pattern. ${ }^{45}$

Artificial intelligence (AI) assists in putting the Big Data gathered to good use by drawing conclusions as to the probability of an event from prior knowledge of conditions related to the event; the greater the volume of data, the more insightful and accurate the inferences drawn from the data. ${ }^{46}$ The

$41 \quad$ See David Yermack, Corporate Governance and Blockchains, 21 REV. FIN. 1, 9 (2017). For an account of the option backdating scandal see e.g. Jesse M. Fried, Option Backdating and Its Implications, 65 WASH. \& LEE L. REV. 853, 858-864 (2008).

$42 \quad$ On the role of compensation consultants compare Kevin J. Murphy \& Tatiana Sandino, Executive Pay and "Independent" Compensation Consultants, 49 J. ACC'T \& ECON. 247-262 (2010) (finding evidence for higher recommended levels of CEO pay when executive compensation consultants "cross-sell" services, but also (somewhat counterintutively) that board pay is higher when consultants work for the board rather than for executives) with Christopher S. Armstrong, Christopher D. Ittner \& David F. Larcker, Corporate Governance, Compensation Consultants, and CEO Pay Levels, 17 REV. ACC'T STUD. 322-351 (2012) (finding that differences in governance quality explain much of the higher pay in clients of compensation consultants, while there is no support for claims that potentially "conflicted" consultants result in higher CEO pay).

$43 \quad$ Hamdani et al., supra note 34, at 229.

44 See VikTor MAYer-Schönberger \& KenNeth Cukier, Big Data: A Revolution that Will Transform how We Live, Work, AND Think 12-14 (2013) (predicting that big data will transform the organization of society).

$45 \quad$ See id., at 6 (stating that the volume of information in the last decades has outpaced IT engineers' manual data handling capacity so that engineers need to reinvent the tools they use for analyzing information; the latter will result in new forms of value creation that affect markets, organizations and other institutions).

46 See Stuart J. Russel \& Peter Norvig, Artificial Intelligence: A Modern APPROACH 495-99 (3d ed., 2016). 
base line of AI is a computer that mimics human cognitive functions, such as "learning" and "problem solving." ${ }^{47}$ Machine learning is a subset of AI that uses statistical, data-based methods to progressively improve the performance of computers on a given task, without humans reprogramming the computer system to achieve enhanced performance. ${ }^{48}$ In practice, the learning is achieved through extensive "practice" with multiple feedback rounds through which the machine is told whether it has passed or failed a task.

\section{AI-based CorpTech}

Due to their superior performance in data gathering and processing, big data analytics, $\mathrm{AI}$ and machine learning (hereinafter, referred to together as "AI") can be expected to affect all operational as well as internal control matters, from strategy setting ${ }^{49}$ to risk management ${ }^{50}$ and compliance. ${ }^{51}$ While humans tend to use core, salient data for decisions, technology can consider not only core, but also seemingly unrelated data.

Further, technology can handle data of the past as effectively as data of the present. This is particularly important for risk management: simply put, people tend to forget. To the extent that accessibility of data of the past by humans (i.e. memory) declines, management of the risk related to those data unduly becomes of secondary importance. AI-based early detection and subsequent mitigation of non-compliance should prove particularly valuable in reducing liabilities, penalties and fines, the magnitude of which has starkly

47

See Russel \& NoRviG, supra note 46, at viii, 1-4 (defining AI as devices that perceive their environment and take actions that maximize their chances of successfully achieving their task and describing the origin of the term AI in the Turing Test where "a computer passes the test if a human interrogator, after posing some written questions, cannot tell whether the written responses come from a person or from a computer", and defining six core capabilities that together compose most of AI, including natural language processing, knowledge representation, automated reasoning, machine learning, computer vision, and robotics). The seminal work on AI is of course Alan M. Turing, Computing Machinery and Intelligence, 49 MIND 433 (1950).

48 RUSSEL \& NORVIG, supra note 46, at 693-859 (describing the training methods).

49 See Armour \& Eidenmüller, supra note 18, at 17 (while "strategic questions considered at the C-suite level" are unlikely to justify machine learning analysis, given the insufficiency of available data, "external generic data can be used to assist in scenario planning.").

$50 \quad$ See Saqib Aziz \& Michael M. Dowling, Machine Learning and AI for Risk Management, in Disrupting Finance. Palgrave Studies in Digital Business \& ENABLING TECHNOLOGIES 33 (Theo Lynn et al. eds., 2019).

51 See Bamberger, supra note 16, at 690-93, 701-02. 
increased in the last decade. ${ }^{52}$

Technology is also said to be unbiased, ${ }^{53}$ albeit in the limited sense that technology does not follow its own agenda and is not itself subject to humans' cognitive biases. ${ }^{54}$ In particular, by airing unconventional and (factbased) contrarian views, machines could neutralize two related group dynamics that seriously hamper boards' effectiveness, namely "groupthink" 55 and the strong social pressure against the expression of dissent in boardrooms. ${ }^{56}$ An oft-cited example of the early adoption of AI to improve board decision-making dynamics involved Hong Kong-based venture capital firm Deep Knowledge Ventures, which assigned a (sort of) board position to an AI software named VITAL. ${ }^{57}$ VITAL's due diligence shall protect the firm from investing in trendy, but overpriced inventions by identifying overhyped projects based on public awareness a certain topic generates. ${ }^{58}$

Better use of internal and external data will also improve intra-firm

52 For instance, the U.S. Federal Trade Commission has approved a fine of approximately five billion dollars against Facebook for mishandling users' personal information. See Cecilia Kang, F.T.C. Approves Facebook Fine of About \$5 Billion (Jul. 12, 2019), N.Y. TimeS, Jul. 12, 2019, at 1. In 2017, German car manufacturer Volkswagen admitted to having manipulated emissions data for cars manufactured for the U.S. markets, resulting, so far, in penalties and damages of nineteen billion dollars. See U.S. Department of Justice, Office of Public Affairs, Volkswagen AG Agrees to Plead Guilty and Pay \$4.3 Billion in Criminal and Civil Penalties; Six Volkswagen Executives and Employees are Indicted in Connection with Conspiracy to Cheat U.S. Emissions Tests (Jan. 11, 2017), https://www.justice.gov/opa/pr/volkswagen-ag-agrees-plead-guilty-and-pay-43-billioncriminal-and-civil-penalties-six.

$53 \quad$ See Gramitto Ricci, supra note 20 at 29; Petrin, supra note 20, at 34-35.

$54 \quad$ But see e.g. Barocas \& Selbst, supra note 5, at 692 (describing the risk that decision makers mask their intentions by using biased data). See also infra notes 121-125 and accompanying text.

55 On groupthink see generally IRVING JANIS, Victims OF GROUPTHINK (1972).

$56 \quad$ See Akshaya Kamalnath, The Perennial Quest for Board Independence-Artificial Intelligence to the Rescue?, 83 AlBANy L. REV. 43, 52 (2020). See generally JonAtHAn R. Macey, Corporate Governance. Promises Kept, Promises Broken 61-62 (2008) (describing the pressure to conform to social norms of collegiality and cooperation within boardrooms).

$57 \quad$ See Gramitto Ricci, supra note 20, at 33-43; Michal S. Gal, Algorithmic Challenges to Autonomous Choice, 25 Mich. TECH. L. REV. 59, 61 (2018); Armour \& Eidenmüller, supra note 18 , at 3 .

$58 \quad$ See Press Release, Deep Knowledge Venture's Appoints Intelligent Investment Analysis Software VITAL as Board Member - Hong Kong Venture Capital Fund Appoints Machine Intelligence as Board Member, May 13, 2014, available at https://globenewswire.com/news-release/2014/05/13/635881/10081467/en/Deep-

Knowledge-Venture-s-Appoints-Intelligent-Investment-Analysis-Software-VITAL-asBoard-Member.html. 
monitoring, which in turn should result in reduced agency costs ${ }^{59}$ and allow for flatter organizational structures. ${ }^{60}$

In particular, AI and big data analytics could improve the design and steering effect of compensation packages. Equilar Inc., a provider of tech solutions for board recruiting, executive compensation and shareholder engagement, provides an early example. Using publicly available compensation disclosures, performance targets and performance data, Equilar's applications generate "pay-for-performance" scores that can be used to determine whether an executive is over- or under-paid relative to executives of similarly situated companies. ${ }^{61}$

\section{CORPTECH'S IMPACT: THE END OF THE BOARD AS WE KNOW IT?}

Since Melvin Eisenberg's seminal book The Structure of the Corporation, corporate law scholars posit that a monitoring board is necessary to keep selfinterested managers at bay and to ensure that shareholder interests are catered to. ${ }^{62}$ Corporate governance practices at U.S. listed companies have increasingly conformed to such a scholarly approach. ${ }^{63}$

Tech proponents argue that shareholders will no longer need boards to monitor managers because shareholders will be able to do the monitoring themselves. ${ }^{64}$ For the same reason, there will be no need for boards to mediate between the company and its management on the one hand, and shareholders on the other. ${ }^{65}$ Finally, because humans are not prepared for the challenges

59 See Nicholas Bloom, Luis Garicano, Raffaella Sadun \& John Van Reenen, The Distinct Effects of Information Technology and Communication Technology on Firm Organization, 60 MGMT. SC. 2859 passim (2014) (finding evidence that better information technologies are associated with more autonomy and a wider control span).

$60 \quad$ See Philippe Aghion, Benjamin Jones \& Charles I. Jones, C., Artificial Intelligence and Economic Growth 23-24, NBER Working Paper 23928 (2017).

61 See Equilar's patent application for its "Equilar Pay for Performance Score," U.S. Patent Office, Patent Application Publication, Pub. No. US 2013/0159067 A1, Pub. Date: Jun. 20, 2013, https://patents.google.com/patent/US20130159067A1/en (detailing the algorithms and data sources used for calculating the score).

62 See Melvin A. Eisenberg, The Structure of the Corporation 156-85 (1976).

63 See Jeffrey N. Gordon, The Rise of Independent Directors in the United States, 1950-2005: Of Shareholder Value and Stock Market Prices, 39 STAN. L. REV. 1465, 151840 (2007) (highlighting how the monitoring board model has prevailed in the U.S. in the decades following Melvin Eisenberg's influential work).

$64 \quad$ See infra Section II.A.

65 On the mediating function of boards, see generally Margaret M. Blair \& Lynn A. Stout, A Team Production Theory of Corporate Law, 85 VA. L. REV. 248, 269-82 (1999) (arguing that the corporation is a "mediating hierarchy" of partially contradicting interests and that the board's core function is to balance those interests to the benefit of the firm). 
presented by tech developments, they may even be replaced, partially or fully, by CorpTech automata. ${ }^{66}$

We lay out the tech proponents' view, first, by relaying their argument that CorpTech will diminish the need for a monitoring and mediating board (section II.A). Second, we present the view that the remaining board tasks can be achieved more efficiently by CorpTech algorithms (section II.B).

\section{A. Obsolescent Boards?}

\section{Real-time Accounting and "Full Transparency"}

According to tech proponents, the days of information asymmetry between a firm's insiders and outsiders are numbered: real-time accounting is expected to replace traditional accounting and firms to voluntarily post their ordinary business transactions on a blockchain accessible to the public. ${ }^{67}$ Shareholders could access the company's entire ledger of transactions. As David Yermack holds, "[a]nyone could aggregate the firm's transactions into the form of an income statement and balance sheet at any time, and investors would no longer need to rely on quarterly financial statements prepared by the firm and its auditors." ${ }^{68}$ Based on the assumption that technology will eventually lead to proprietary information being shared with investors and other market participants, these commentators argue that full transparency will increase shareholder trust in the integrity of a corporation's data and render costly audits by potentially corrupt professional firms useless. ${ }^{69}$ In turn, greater transparency, coupled with enhanced post-trade efficiency, will reduce transaction costs and improve liquidity in capital markets. ${ }^{70}$

Ultimately, tech proponents expect lower agency costs arising in connection with the selection of directors and executives, ${ }^{71}$ accrued earnings

\footnotetext{
$66 \quad$ See infra Section II.B.

67 Yermack, supra note 41, at 18, 24-25.

$68 \quad I d$. at 24.

69 Id at 24-25; OECD, DiRECTORATE FOR FINANCIAL AND ENTERPRISE AFFAIRS Corporate Governance Committee, Blockchain Technology and Corporate Governance - TeChnology, MARKets, Regulation And Corporate Governance 2425 (2018); see also Reyes, Packin \& Edwards, supra note 15, at 18-21 (albeit more cautiously as to the whether such a setup is desirable).

$70 \quad$ Yermack, supra note 41, at 18.

$71 \quad$ Hamdani et al., supra note 34, at 229; Kamalnath, supra note 56, passim. See also Isil Erel, Léa H. Stern, Chenhao Tan \& Michael S. Weisbach, Selecting Directors Using Machine Learning, European Corporate Governance Institute (ECGI) - Finance Working Paper No. 605/2019 (2018) (describing an experiment with algorithms to make out-ofsample predictions of director performance, using shareholder approval rates as well as firm
} 
management, ${ }^{72}$ related party transactions ${ }^{73}$ and management compensation systems. ${ }^{74}$ That should vanquish the need for boards to focus on such issues. ${ }^{75}$

\section{More Direct Shareholder Influence}

The optimism regarding enhanced transparency is not limited to accounting data, but extends to transparency of ownership ${ }^{76}$ prompting the view that DLT-induced transparency could replace mandatory disclosure of beneficial ownership and prevent empty voting. ${ }^{77}$

More generally, according to Yermack, DLTs have the potential of "dramatically affect[ing] the balance of power between directors, managers, and shareholders." 78 Greater transparency on trading and ownership data may erode profit opportunities for active traders, shareholder activists and raiders, while the (supposed) increased liquidity of a blockchain-based market would reduce the costs of selling and may therefore lead to more emphasis being placed on exit (trading) as opposed to voice (voting). ${ }^{79}$ This would reduce the importance of the board as a mediator among shareholder constituencies with diverging interests.

At the same time, a private distributed ledger recording shareholder voting could increase speed and accuracy, thereby reducing voting costs and

returns and profitability as proxies, testing the quality of these predictions, and concluding that " $[\mathrm{m}]$ achine learning holds promise for understanding the process by which governance structures are chosen, and has potential to help real-world firms improve their governance."). 72 Yermack, supra note 41, at 25.

$73 \quad$ Id

74 Hamdani et al., supra note 34, at 229; Yermack, supra note 41, at 20-21 (also noting, though, that blockchain trading of a company's shares may reduce the effectiveness of equity-based management incentives: assuming that part of management's compensation is legal insider trading (i.e. trading in compliance with insider trading laws), he predicts realtime transparency to prompt less active managerial trading out of concern of sending adverse signals to the market. In turn, if management profits less from legal insider trading, firms might have to pay management more to offset their foregone gains.

$75 \quad I d$. at 20-21, 25; Hamdani et al., supra note 34, at 229.

76 See Geis, supra note 13, at 255-262 (discussing distributed ledgers and blockchain for creating traceable shares in the clearing and settlement system) and 267-269 (arguing that traceable shares lead to a fully transparent "centralized ledger of owners").

77 Yermack, supra note 41, at 24 (arguing that the tech-based increase in transparency will render empty voting more difficult). Empty voting refers to the exercise of shareholder voting rights without the underlying economic interest. See Henry T. C. Hu \& Bernard Black, The New Vote Buying: Empty Voting and Hidden (Morphable) Ownership, 79 S. CAL. L. REV. 811, 828-36 (2006).

$78 \quad$ Yermack, supra note 41, at 9.

79 Id. at $19-20$. 
increasing shareholder participation. ${ }^{80}$

The blockchain also allows for decentralized, "virtual-only" shareholder meetings, ${ }^{81}$ which may induce shareholders to demand votes on a wider range of topics and with greater frequency than today. All in all, the advent of CorpTech would justify the opening of "a debate for a new equilibrium of the division of powers between the shareholders and the board of directors." 82 This could result in shareholders assuming indirect control over management, reducing the need for board monitoring. ${ }^{83}$

\section{B. Towards Algo-Boards?}

An even bolder prediction is that machines will replace human-populated boards. There are two components to this view: first, board functions are becoming more challenging for humans, ${ }^{84}$ and, second, CorpTech solutions will be able to perform board functions better than humans.

With firms depending more and more on technology, and in an environment increasingly characterized by uncertainty and constant disequilibrium, ${ }^{85}$ humans may become less fit to serve as board members than machines. ${ }^{86}$ Humans may also be less willing to do so: in a fully ITdominated environment they will be increasingly incapable of reviewing and overseeing self-learning algorithms and yet, as board members, their reputation will be on the line if such algorithms prove to be deficient.

CorpTech could step in and replace human directors as corporate monitors: Hamdani et al. suggest that "AI algorithms may become better on average at making governance decisions than individuals due to their superior ability to process information, freedom from biases, and lack of side interests." ${ }^{87}$ If one role is left to the monitoring board, it is in the choice of

Id. at 23; Geis, supra note 13, at 267-69, 272-73 (arguing that DLT can enhance voting turnout and reduce the costs of shareholder activism); DE FILIPPI \& WRIGHT, supra note 7 , at 133-36.

$81 \quad$ Lafarre \& Van der Elst, supra note 15, at 25.

$82 \quad I d$.

$83 \quad$ Bankewitz et al., supra note 19, at 63.

$84 \quad$ See e.g. Id. at 65.

85 See e.g. Mark Fenwick \& Erik P.M. Vermeulen, Technology and Corporate Governance. Blockchain, Crypto, and Artificial Intelligence, 48 TEXAS J. Bus. L. 1, 2 (2019) (predicting that firms face new "conditions of radical cognitive and normative uncertainty."). 86 See Id. at 8-10 (speculating about AI replacing board functions); Florian Möslein, Robots in the Boardroom: Artificial Intelligence and Corporate Law, in RESEARCH HANDBOOK ON THE LAW OF ARTIFICIAL INTELLIGENCE 649, 649-50 (Woodrow Barfield \& Ugo Pagallo eds., 2019) (predicting use of AI in the boardroom).

$87 \quad$ Hamdani et al., supra note 34, at 229. 
algorithms. ${ }^{88}$ Liberated from their monitoring tasks, boards could focus on strategic advice instead. ${ }^{89}$ Board composition would change accordingly: more business and fewer accounting and monitoring experts would be needed. ${ }^{90}$

But a more radical prediction is that boards will not necessarily continue to exist as we know them, namely as a group of humans. In this view, boards' functions, or board seats, may rather be taken over by algorithms. While qualifying VITAL, ${ }^{91}$ Alicia $\mathrm{T}^{92}$ and other AI as board members may be nothing more than a publicity stunt, the discussions on whether legal personality (so-called e-personhood) should be assigned to algorithms ${ }^{93}$ and whether algorithms should be allowed to sit on boards ${ }^{94}$ signal CorpTech's intrusion into the legal domain.

\section{The DeMise OF THE BoARD: A TECH NiRVANA FALlaCy}

Can board functions be automated to the point of making corporate boards superfluous, as the tech proponents predict? ${ }^{95}$

We argue in this section that, at least for the predictable future, the tech proponents' view is an expression of the tech nirvana fallacy, that is, the tendency to contrast a perfect technology-enhanced but hypothetical world with the real, imperfect one in which humans currently live. In other words, the tech proponents' view reflects an excessively optimistic view about the present (and predictable) capabilities of the salient technological developments, while disregarding the persistence of humans' interaction with, and influence on, technology.

We develop our tech nirvana fallacy argument in three steps. First, we briefly describe what boards do and why they do it (section III.A). We then take on the prediction that machines will make the monitoring board

\footnotetext{
$88 \quad$ Id. at 230.

89 Id.; Mark Fenwick, Joseph A. McCahery \& Erik P.M. Vermeulen, The End of "Corporate” Governance: Hello "Platform" Governance, 20 EuR. Bus. ORG. L. REV. 171, 191-197 (2019).

$90 \quad$ Hamdani et al., supra note 34, at 230.

$91 \quad$ See supra text accompanying notes 58

92 Alicia T is the nickname of an AI executive of Finnish software company Tieto. See Antony Peyton, Alicia key to Tieto's AI leadership team, 19 Oct. 2016, available at: https://www.bankingtech.com/2016/10/alicia-key-to-tietos-ai-leadership-team/.

93 See European Parliament resolution of February 16, 2017, with recommendations to the Commission on Civil Law Rules on Robotics 3 (2015/2103(INL) http://www.europarl.europa.eu/doceo/document/TA-8-2017-0051_EN.pdf. But see Gramitto Ricci, supra note 20, at 21-23 (arguing against e-personhood).

94 See Gramitto Ricci, supra note 20, at 31-33.

95 See the discussion supra Section II.B.
} 
redundant (section III.B), before challenging the claim that technology will enable shareholders to oversee managers directly and make mediating boards obsolete (section III.C). We conclude that, although CorpTech will improve boards' performance, their present core functions will remain unchanged.

\section{A. Boards' Core Functions}

Before discussing why the tech proponents' view suffers from a tech nirvana fallacy, let us first briefly review why we have boards and what they do. Although most readers will be familiar with these concepts, a brief account of boards' core functions will set the stage for the following analysis of why technology in the foreseeable future will not displace boards.

The Delaware General Corporation Law (DGCL), as the most important state legislation on corporate law, states that the "business and affairs of every corporation ... shall be managed by or under the direction of a board of directors." 96 In practice, however, boards do not manage corporations, but rather steer them by monitoring the top management, in an effort to reduce agency costs. ${ }^{97}$ Boards also engage as mediators with a view to reducing conflicts with and among shareholders and stakeholders. ${ }^{98}$

\section{The Monitoring Board}

Collective action problems among dispersed shareholders, coupled with their

96 DEL. COD. ANN., tit. 8., § 141(a) (2016).

97 See EISENBERG, supra note 62, at 165 (stating that directors' task is to hold executives accountable for adequate results); STEPHEN M. BAINBRIDGE, CORPORATE LAW 80 (3d ed. 2015) ("Among the [various board's functions] [...], the board's monitoring role reigns supreme").

98 See Lynne L. Dallas, The Relational Board: Three Theories of Corporate Boards of Directors, 22 J. CORP. L. 1, 4-8 (1996) (stating that, in addition to monitoring, the board assumes a relational role with the external environment including information access and exchange, support of corporate business and ensuring legitimacy and status in the eyes of shareholders and stakeholders); Lynne L. Dallas, Proposals for Reform of Corporate Boards of Directors: The Dual Board and Ombudsperson, 54 WASH. \& LEE L. REV. 91, 101 (1997) (outlining the relational role of boards). 
limited access to information, ${ }^{99}$ leave room for managerial opportunism. ${ }^{100}$ In particular, shareholders have traditionally been unable to act upon any negative signal about managerial performance other than by voting with their feet. ${ }^{101}$

A well-functioning board of directors can reduce agency costs: ${ }^{102}$ an independent board may do better than shareholders at monitoring managers on their behalf. Directors can combine the signals of inferior performance coming from stock prices ${ }^{103}$ with their access to inside information ${ }^{104}$ in order to gain a better sense of whether negative relative stock performance is due to incompetence, bad luck, or neither: they may well come to the conclusion that managers are simply ahead of their times, i.e. busy implementing an idiosyncratic vision that the market is yet unable to comprehend and/or price correctly. ${ }^{105}$ Directors also have the incentives to take the necessary steps, because not only are their reputations on the line if they remain passive, ${ }^{106}$ but they are also increasingly compensated with stock options that are of no value unless the company's stock performance is positive. ${ }^{107}$

Directors are therefore in the position of fruitfully engaging with managers if their company is underperforming and determining whether the

99 See RoBERT C. Clark, Corporate LAW 95 (1986) (detailing the effects of rational apathy on shareholder voting). See also Lynn A. Stout, New Thinking on "Shareholder Primacy," 2 ACC'T, ECON. \& L. 7 (2012) (stating that "shareholders' own rational apathy raises an often-insurmountable obstacle to collective action.”).

100 See e.g Oliver Williamson, The ECONOMic Institutions of CAPITAlism 47-9 (1985) (stating that opportunism involves self-interested behavior with elements of ploy, deception, misrepresentation or bad faith, resulting in management's appropriation of assets or shirking).

101 See e.g. Edward B. Rock, The Logic and (Uncertain) Significance of Institutional Investor Activism, 79 GEO. L.J. 445, 453-57 (1991).

102 In addition to boards, other mechanisms that reduce agency conflicts include reputational incentives, the market for managerial services, the takeover market and compensation schemes. See e.g. Bernard S. Black, Agents Watching Agents: The Promise of Institutional Investor Voice, 39 UCLA L. REV. 811, 831 (1992) (providing a list of nonlegal constraints on managerial behavior).

103 See Gordon, supra note 62, at 1563.

$104 \quad$ See Enrichetta Ravina \& Paola Sapienza, What Do Independent Directors Know? Evidence from Their Trading, 23 REV. FIN. STUD. 962 (2009) (finding that independent directors earn positive and substantial abnormal returns when trading in their company shares, which is of course an indication of superior information compared to the market as a whole).

105 See Zohar Goshen \& Assaf Hamdani, Corporate Control and Idiosyncratic Vision, 125 YALE L.J. 560 (2016).

106 See generally Armour, Hansmann \& Kraakman, supra note 102, at 35 (describing independent directors as "guided more strongly by conscience and reputation in making decisions.").

107 See e.g. David Yermack, Remuneration, Retention, and Reputation Incentives for Outside Directors, 59 J. Fin. 2281, 2286-88 (2004). 
CEO should stay or go. But, of course, monitoring goes way beyond that; in particular it includes three additional tasks.

First, oversight of management implies some degree of involvement in strategy setting: ${ }^{108}$ a board formally approves a company's strategies, but it does so based on top managers' proposals and the information made available to it by the latter. Given the information disadvantage of (outside) board members, ${ }^{109}$ they are unlikely to be in a position to really define a company's strategy. That is why a board's approval of strategies is better understood as part of its monitoring function: a board reviews the top managers' definition and implementation of the company's strategy more as a sounding board than as a (real) decision-maker. ${ }^{110}$

In addition, a board's monitoring function, usually via one or more of its committees, focuses on the corporation's governance, risk management and compliance (hereinafter, "GRC") systems. ${ }^{111}$ The board's oversight on GRC systems aims to ensure that, first, the level and characteristics of the risks undertaken by the company are consistent with its risk profile (as resulting also from its strategies), second, that the risk of infidelity on the part of managers and employees is kept low and, third, that violations of the law are reasonably prevented.

Finally, boards deal with inherent as well as occasional conflicts of interest between managers and the corporation, to ensure the corporation's interest prevails, in particular with regard to executive compensation and selfdealing. 112

\section{The Mediating Board}

In the last few decades, with the reconcentration of ownership in the hands of institutional investors ${ }^{113}$ and the rise of giant asset management companies, ${ }^{114}$ boards' tasks have partly changed. It is the norm, today, for institutional shareholders to engage in a dialogue with both company officers

108 See e.g. Renée B. Adams \& Daniel Ferreira, A Theory of Friendly Boards, 62 J. FIN. 217, 218 (2007).

$109 \quad$ Id.

$110 \quad$ Id.

111 See e.g. Geoffrey P. Miller, The LaW of Governance, Risk Management, AND COMPLIANCE 73, 543 (2014).

112 See e.g. MACEY, supra note 56, at 51-54.

113 See e.g. Lucian A. Bebchuk, Alma Cohen \& Scott Hirst, The Agency Problems of Institutional Investors, 31 J. ECON. PERSP. 89, 91-93 (2017).

114 John C. Coates, The Future of Corporate Governance Part I: The Problem of Twelve 2, Harv. Public Law Working Paper No. 19-07 (2018) (predicting that control of most public companies will soon be concentrated in the hands of a very small number of people, i.e. large management companies). 
and independent directors. Whether boards should engage in such a relational role has been the subject of discussion among U.S. corporate law scholars, ${ }^{115}$ but corporate practice has bypassed the theoretical dispute.

In recent years, institutional investors have pushed hard to establish two-way communication between (non-executive) directors and themselves, ${ }^{116}$ thereby breaking management's previously held monopoly in dealing with shareholders. As a matter of fact, the continuous dialogue between a company and its shareholders is increasingly carried out by boards, ${ }^{117}$ turning mediation into a second core function of boards.

\section{B. Automation of Monitoring as the Solution?}

We argue in this section that CorpTech is unlikely to make better board-level decisions than human-populated boards. In turn, the assertion that a

115 Compare John C. Coates IV, Measuring the Domain of Mediating Hierarchy: How Contestable Are US Public Corporations?, 24 J. CORP. L. 837, 840-46 (1999) (detailing cases when the mediating models fails) and Stephen M. Bainbridge, Director Primacy: The Means and Ends of Corporate Governance, 97 Nw. U. L. REV. 547, 559-560 (2003) (arguing that the mediating model has a small domain) with Dallas, The Relational Board, supra note 98, at 3, and John H. Matheson \& Brent A. Olson, Corporate Cooperation, Relationship Management, and the Trialogical Imperative for Corporate Law, 78 MINN. L. REV. 1443, 1446 (1994) (arguing that the board is the right organ to mediate among shareholders and management and holding that relationship management is part of the board's fiduciary duties). See also, with a non-shareholder constituency perspective, Blair \& Stout, supra note 65, at 288, and more generally, Margaret Blair \& Lynn Stout, Director Accountability and the Mediating Role of the Board, 79 WASH. U.L.Q. 403, 423-438 (2001) (arguing that corporate law supports the board's mediating role).

116 See Giovanni Strampelli, Knocking at the Boardroom Door: A Transatlantic Overview of Director-Institutional Investor Engagement in Law and Practice, 12 VA. L. \& BUS. REV. 187, 199 (2018) (reporting that U.S. corporations increasingly involve boards, in addition to management, in the dialogue with their shareholders). See also Jill Fisch \& Simone M. Sepe, Shareholder Collaboration 14-15, ECGI Law Working Paper № 415/2018 (arguing that in a new collaborative model "today's institutional investors bring their knowledge of the market rather than just capital to firms, most often concerning corporate governance and strategic planning").

117 See Stephen M. Bainbridge \& M. Todd Henderson, Boards-R-Us: Reconceptualizing Corporate Boards, 66 STAN. L. REV. 1051, 1061 (2014) (arguing that shareholder relationship management is an important board task). See also Strampelli, supra note 116, at 197-200 (reporting that boards, in addition to management, engage in dialogue with shareholders). See also McKinsey \& Co., The BoArd Perspective - Number 2: A COLlection of MCKinsey Insights FOCUSING ON BOARDS OF DiRECTORS 49 (Mar. 2018), available at https:/www.mckinsey.com/featured-insights/leadership/the-board-perspectivenumber-2 (stating that in 2017 boards have spent $9 \%$ of their meeting time on shareholder and stakeholder management, up from $0 \%$ in 2013). 
CorpTech board is super-human, in the sense that it easily passes the test of human parity when compared to a CorpTech-supported human-populated board, rests, on the one hand, on an overly optimistic assessment of what technology can do, and, on the other, on an overly simplistic view of a board's current functions. We predict a more limited role for CorpTech in the boardroom: similar to how, up until today, operational, financial, legal, accounting, or risk experts advise boards, which then come to their own conclusions based on those experts' input, CorpTech can and will inform board members about options and opportunities but cannot replace them.

We first discuss the tech-based arguments against the demise of the monitoring board (III.B.1) and then turn to the inherent traits of corporate governance that justify the prediction of monitoring as a persistent function of corporate boards (III.B.2).

\section{IT Limitations}

Technology may help address humans' cognitive biases and decision-making errors. ${ }^{118}$ But technology has its own limits, which makes the proposed scenario of machines replacing boards unrealistic. Some of these limits ${ }^{119}$ are outlined in this section. In their presence, boards will prove themselves to be necessary complements to CorpTech: in other words, they are bound to add value by remedying CorpTech's deficiencies (and the other way round).

\section{a. Data dependency}

Predictions identify patterns in past data and offer them as projections about future events, basically assuming that history will repeat itself one way or another. ${ }^{120}$ Hence, an algorithm is only as good as the data it works with. Where data of the past reflects biases, so too will the machine results: ${ }^{121}$ the data could reflect the biases of prior decision-makers ${ }^{122}$ or biases that persist

118 See e.g. Cass R. Sunstein, Algorithms, Correcting Biases, 86 SoC. RES. 499, passim (2019) (arguing that algorithms can be designed to be unbiased and perform certain tasks better than biased humans). But see Sandra G. Mayson, Bias In, Bias Out, 128 YALE L.J. 2218, 2251 (2019) (arguing that it "is possible to replace one form of disparity with another, but impossible to eliminate it altogether").

119 We do not discuss two other obvious IT issues: deficient coding as a result of human inaccuracy and exposure to cyber risks. While troublesome, they are not relevant for our purposes as they do not have any specific implication as regards CorpTech.

$120 \quad$ See Mayson, supra note 118, at 2251.

121 See Barocas \& Selbst, supra note 5, at 617; Mayson, supra note 118, at 2251-52.

122 See Rashia Richardson, Jason M. Schultz \& Kate Crawford, Dirty Data, Bad Predictions: How Civil Rights Violations Impact Police Data, Predictive Policing Systems, 
in society at large. ${ }^{123}$ In most cases, the developers are unaware of either any particular deficiencies in the data set or the ensuing discrimination. ${ }^{124}$ Take the example of social media's self-pricing advertising algorithm for educational ads. An algorithm designed to be gender-neutral still steered advertising for science, technology, engineering and mathematics courses to more men than women because the algorithm priced advertisement to women higher than advertisement to men; as a consequence, for a given budget more men than women were exposed to the advertisement. ${ }^{125}$

Furthermore, AI's predictive capabilities depend on the training data. The "learning" of a self-learning machine refers to identifying patterns (i.e. a recurring subset of characteristics) in existing data sets where instances of, say, securities fraud are labeled as such. The machine then looks for patterns among the labeled cases without using explicit instructions. That subset of recurring characteristics can then be used for all other data sets. Where the subset characteristics are found to be present, the machine will assume that securities fraud is also present. What the machine "learns" depends on the examples it has been exposed to, as well as on the quality of the labeling. The closer the training data to the real-world application, the better the predictive ability of the AI. ${ }^{126}$ For instance, a data set taken from Enron Corporation has often been used to train many AI-enhanced compliance tools. ${ }^{127}$ As we know today, Enron's internal communication methods and (bad) governance were in many respects outliers, even relative to the less governance-aware

and Justice, 94 N.Y.U. L. REV. 192, 204-217 (2019) (detailing examples of manipulated data in the criminal justice system, reflecting racial bias).

123 See Barocas \& Selbst, supra note 5, at 617 (stating that "data mining can discover surprisingly useful regularities that are really just preexisting patterns of exclusion and inequality.").

124 Conscious choices may, however, be the result of conflicts of interests (see infra, Section III.B.2.b). And lack of awareness does not exclude racially or gender biased, or otherwise illegal, practices. See Richardson et al., supra note 122, at 193-97 (detailing examples of such practices in the context of predictive policing).

125 See Anja Lambrecht \& Catherine Tucker, Algorithmic Bias? An Empirical Study into Apparent Gender-based Discrimination in the Display of STEM Career Ads, 65 MGMT. Sc. 2966 (2019) (analyzing an advertisement algorithm intended to be gender-neutral in its delivery and concluding that any algorithm that simply optimizes cost-effectiveness in ad delivery will deliver ads in an apparently discriminatory way).

126 See RUSSEL \& NORVIG, supra note 46, at 706-08 (describing preconditions of learning from examples).

$127 \quad$ See Armour \& Eidenmüller, supra note 18, at 14 (stating that machine learning developers use coaching data from widely available data sets, such as the Enron email data set that was originally put online by the U.S. Federal Energy Regulation Commission (FERC)). The data set contains data from about 150 users, mostly senior management of Enron, with a total of about $0.5 \mathrm{M}$ messages, and is available for download at https://www.cs.cmu.edu/ ./enron/. 
corporate world of Enron's times. ${ }^{128}$ AI trained with outlandish, outdated and incomplete ${ }^{129}$ data from Enron will lack predictive accuracy for most firms.

Firms may seek to enhance predictive accuracy by training the AI with data generated inside their own organization. In this case, data availability may emerge as an issue. Even where firms have the right to use or transfer data, ${ }^{130}$ small- and medium-sized firms are likely to lack data pools of sufficient size to train the technology, ${ }^{131}$ while large firms that collect sufficient data may hesitate to share firm-specific data with external developers: in an environment where "data is the new oil," 132 these data may be too valuable to share as they, or the training results thereof, can be, respectively, copied and (once incorporated into services) sold to competitors. Worse still, external developers may become competitors themselves after assembling a large enough data pool. ${ }^{133}$

Finally, finding some regularities in past data (however recent and "big") is more useful in some areas, such as medical diagnoses and stock trading, than in others, such as social dynamics. Human behavior is not totally predictable, as markets and people's preferences evolve. Because humans adapt to changes, responses to a given context that were observed regularly in the past will not necessarily be good predictors of the future. To generalize, correlations between complex, dynamic human phenomena that interact with other organizations and an indefinite number of individuals (stakeholders, consumers, etc.), are poor predictors of future outcomes.

The data dependency problems highlighted so far reflect the current state of the relevant technologies. These problems are likely to be overcome in the future. For instance, an application for bias analysis may recognize

128 See e.g. John C. Coffee Jr., What Caused Enron - A Capsule Social and Economic History of the 1990s, 89 CORNELl L. REV. 269, passim (2004); CuRTIS J. MilHAUPT \& Katharina Pistor, LAW AND CAPITAlism: What Corporate CRisis ReveAl About Legal Systems AND ECONOMiC DeVElopment AROUND THE World 47-67 (2008) (discussing the Enron scandal).

129 The e-mails' text had been redacted in response to privacy concerns and attachments to messages had been deleted to reduce data size. See William W. Cohen, Enron Email Dataset (2015), https://www.cs.cmu.edu/ ./enron/.

130 The data pool available for Corptech training may be limited by legal barriers, including data protection, intellectual property laws and confidentiality agreements signed with customers and business partners. See Armour \& Eidenmüller, supra note 18, at 15-16. $131 \quad$ Id.

132 The origin of this sentence is uncertain. One of the earliest sources to use it dates back from 2006. See Michael Palmer, Data is the New Oil, Nov. 3, 2006, http://ana.blogs.com/maestros/2006/11/data_is_the_new.html.

133 See Dirk A. Zetzsche, Ross P. Buckley, Douglas W. Arner \& Janos N. Barberis, From FinTech to TechFin: The Regulatory Challenges of Data-Driven Finance, 14 N.Y.U. J.L. \& Bus. 393, 399-415 (2018) (analyzing the entrance of big data firms like Alibaba, Amazon, Apple, Baidou, and Google into the financial services sector). 
and remedy the impact of biased data; ${ }^{134}$ and the publicly available data pools can become large enough to allow for accurate training. Even then, however, the core issue with data dependency, namely, its backward orientation, will remain unresolved: in real life, it is normally the case that the right answers to the questions defining the success or failure of a firm, such as whether to enter a new market or to leave the CEO in place, cannot be found in past data. AI-based predictions can effectively support those decisions, but in the end something very human is required: judgment. ${ }^{135}$

\section{b. Conflicts with human ethics}

Morally wrong determinations can seriously harm a firm's reputation and its share price, ${ }^{136}$ and this is why reputational risk is a core consideration of GRC functions. Were CorpTech to make such decisions, the risk of unethical determinations revealing themselves to be spectacular mistakes would skyrocket. That is because training machines in ethical matters is an impossible challenge, as "[ethical] norms are fuzzy." ${ }^{137}$ Even humans often cannot tell what prompts their value judgments. In a CorpTech world, human boards are thus required to align corporate behavior with mainstream ethics.

\section{c. Inferior handling of incomplete law}

Where an incident (a violation of the law or an employee's wrongdoing) is reported, the corporate response will depend on a unique combination of

134 See Rumman Chowdhury \& Narendra Mulani, Auditing Algorithms for Bias, HARV. BuS. REV. ONLINE (Oct. 24, 2018), https://hbr.org/2018/10/auditing-algorithms-for-bias (presenting a tool developed by Accenture and the Alan Turing Institute that measures the discriminatory impact of big data applications and corrects for predictive parity to achieve equal opportunity).

135 See Surden, supra note 6, at 97-98 (arguing that AI approximates intelligence by detecting proxies, patterns, or heuristics, and emphasizing that many complicated problems "may not be amenable to such a heuristic-based technique" and using the decision on a potential merger as an example, given the scale, complexity, and nuance, and the need to account for so many dimensions, that a simple approximation would be inappropriate); Mohammad Hosssein Jarrahi, Artificial Intelligence and the Future of Work: Human-AI Symbiosis in Organizational Decision Making, 61 Bus. HorIzons 577, 580 (2018) (arguing that " $[\mathrm{u}]$ nlike board games, in which the probability of the next action can be calculated, real-world decision making is messy and reliance on probabilistic, analytical thinking tends to be insufficient.").

136 For instance, Facebook's PR firm scandal cost Facebook 9\% of its share price on a single day, or $\$ 36$ billion, which is slightly less than the total value of carmaker Ford. See Salvador Rodriguez, Here Are the Scandals and Other Incidents That Have Sent Facebook's Share Price Tanking in 2018, CNBC (Nov. 20, 2018 4:31PM), https://www.cnbc.com/2018/11/20/facebooks-scandals-in-2018-effect-on-stock.html.

137 Eric A. Posner, Law, Economics, and Inefficient Norms, 144 U. PA. L. REV. 1697, 1699 (1996). 
factors. In fact, most GRC issues imply discretion, even for cases that are very similar to prior ones. Hence, a pre-determined $1 / 0$, yes/no algorithm will be unable to reach good decisions on how to react. ${ }^{138}$ This is the inevitable implication of the incompleteness that characterizes the legal environment, where not only are contracts incomplete, but so too is the law itself: ${ }^{139}$ neither contracts nor the law can provide for clear-cut rules for every situation. Drafting exhaustive contracts and laws would be incredibly expensive and, in fact, outright impossible, and so too would the creation of a CorpTech solution attempting to do just that. ${ }^{140}$ Governance arrangements themselves are incomplete on purpose, ${ }^{141}$ and hence unfit for strict tech-based execution.

Even where a board finds that management is responsible for a GRC failure, a formal sanction might not always be warranted: handling GRC situations will often involve an aspect of judgment and/or adjudication under conditions of significant uncertainty regarding the response of the sanctioned person(s) and that of stakeholders (including employees, the public and others). This results in the discretionary, creative and non-rule based decision-making that is, at least for the predictable future, part of the human skillset that machines are unlikely to be able to replicate. ${ }^{142}$ In an environment

$138 \quad 1 / 0$ is the paradigm of Boolean logic. But human judgment follows neither Boolean logic nor any other conventional mathematical discipline. This is also true when you soften the $0 / 1$ paradigm using probability theory or fuzzy logic (since fuzzy logic can operate with all infinite values within the interval $<0,1>$. See e.g. Václav Bezděk, Using Fuzzy Logic in Business, 124 Procedia - Soc. \& Behavioral ScI. 37 1, 372-379 (2014)). Whether an observer holds an incident to be probable (from her subjective point of view) or whether she puts an incident into the "more negative rather than positive" box (using fuzzy logic, which requires preferences in a given order) is the outcome of an ethical assessment applying an $\mathrm{ad}$ hoc mix of factors and resulting in the qualification of conduct as likely (probability) or "more harmful than helpful" (fuzzy logic). If the factors that justify 0 or 1 , a given probability assessment or the preferences for fuzzy qualification are impossible to discern ex ante, they cannot be put into code.

139 See generally Herbert L.A. HART, The CONCEPT OF LAW (2d ed., 1994), 127-28, and, more recently, Katharina Pistor \& Chenggang Xu, Incomplete Law, 35 N.Y.U. J. INT'L L. \& POL'Y 931, 938-44 (2003). With specific reference to compliance issues, see Donald C. Langevoort, Caremark and Compliance: A Twenty Year Lookback, 90 TEMPLE L. REV. 727 (2018) (arguing that "complication arises from the subjective nature of law and legal risk. Law is often full of ambiguity, even when factual questions are posed clearly."). See also Joshua P. Davis, Artificial Wisdom? A Potential Limit on AI in Law (and Elsewhere) 72 OKLA. L. REV. 51, 61-65 (2019) (arguing that AI is incapable of mimicking value-based decisions since it misses the first person perspective).

140 See Aghion et al., supra note 60, at 41-42 (arguing that AI technologies will not overcome contractual incompleteness).

141 See infra at III.B.2.

142 See Dylan Hadfield-Menell \& Gillian K. Hadfield, Incomplete Contracting and AI 
that is otherwise under the increasing influence of technology, the board brings in the unpredictable, yet indispensable human factor. ${ }^{143}$

\section{Governance's Inherent Traits}

a. The incomplete corporate contract

A corporation is often described as a nexus of contracts, ${ }^{144}$ that is, a bundle of formal and informal relationships among the various stakeholders. These contracts are incomplete, and intentionally so, since writing a multiplicity of complete contracts between a firms' stakeholders would be either excessively costly or unduly constraining. ${ }^{145}$ For these reasons, governance arrangements are incomplete on purpose, and hence unfit for strict tech-based execution. It is a board's task to continue writing chapters of the corporate contract where necessary. Corporate governance provides the tools to deal with such incompleteness: as circumstances change and new information becomes available, management, boards and shareholders react by making decisions, each in their own sphere, that allow for adaptation and optimization to a degree that ex ante planning could not match. ${ }^{146}$

CorpTech will not eradicate contractual incompleteness, whether by perfect ex ante planning or by better-than-human ex post decisions. Such eradication would require not only access to, and correct processing of, all existing data in the world (something that CorpTech may well provide for in the future), but also the ability to predict all future developments. In a non-

Alignment, Proc. 2019 AAAI/ACM ConF. ON AI, ETHICS, \& SoC'Y 417, at 419-20 (2019) (arguing that coders are yet incapable of replicating norms and standards that grant discretion to their addressees).

143 This is not to deny that humans, and human-populated boards, make mistakes too. See infra text notes 147-152.

144 See e.g. Frank H. Easterbrook \& Daniel R. Fischel, The Corporate Contract, 89 COLUM. L. REV. 1416, 1426 (1989).

145 See generally Frank H. EASTERBROOK \& DANIEL R. Fischel, The ECONOMIC STRUCTURE OF CORPORATE LAW 91-93 (1991). This point is acknowledged in the literature on new technologies. See Sklaroff, supra note 8, at 263 (arguing that human-based contracting is flexible due to inherent incompleteness, while machine-based contracting creates new inefficiencies from automation, decentralization and anonymity); Adam J. Kolber, Not-So-Smart Blockchain Contracts and Artificial Responsibility, 21 STAN. TECH. L. REV. 198 (2018) (arguing that the code does not reflect the entirety of the parties' agreement); Hadfield-Menell \& Hadfield, supra note 142, at 421-22 (emphasizing "parallels between the challenge of incomplete contracting in the human principal-agent setting and the challenge of misspecification in robot reward functions.").

146 See generally Easterbrook \& Fischel, supra note 144, at 1437-39 (arguing that the contract adopted as optimal ex ante may not be optimal ex post, for instance due to changing circumstances such as a takeover bid). 
deterministic world like the one that humans inhabit, and where humans still take meaningful decisions, such eradication exceeds what even the most powerful machines can muster. Any set of codes predicting future events would require a significant level of speculation and thus would be certain to be flawed (notwithstanding its high costs).

To be sure, the benchmark of technology, and AI in particular, is not perfection, but human parity. ${ }^{147}$ Any CorpTech solution yielding better monitoring outcomes than human boards would justify algorithmic boards. And it is easy to acknowledge that human boards are themselves far from perfect in writing the incomplete corporate contract. Arguably, they are also limited in their ability to learn, as recurring governance scandals demonstrate. Still, one thing human boards are, and can be predicted to be for a long time, better at than CorpTech are complex interactions with humans. ${ }^{148}$ Take the example of the WellsFargo scandal. ${ }^{149}$ The bank was forced to switch to political mode and face, among others, multiple U.S. House and Senate Committee hearings, ${ }^{150}$ in order to minimize the reputational fallout. ${ }^{151}$ Such a mode includes intense lobbying action, public relations efforts, and generally presenting in a positive light a firm's corporate culture, values and ethics. Soft skills and fuzzy matters such as these are unsuitable for automation: ${ }^{152}$ any sufficiently intricate, politically charged matter requires humans to interact with humans.

\section{b. Conflicts of interest}

An algorithm is not an "impartial" tool: it assists its creators in settling affairs within a community according to their preferences. ${ }^{153}$ So long as algorithms are written by humans and, even more importantly, sold to humans, claims

147 See generally RUSSEL \& NORVIG, supra note 46, at 2-3 (arguing that the testing standard of artificial intelligence is human parity).

148 Simple communication between machines and humans does take place regularly and frequently.

$149 \quad$ See supra note 1 and accompanying test.

$150 \quad$ See e.g. Holding Megabanks Accountable: An Examination of Wells Fargo's Pattern of Consumer Abuses: Hearing Before the H.R. Comm. on Fin. Serv., 116th Cong. (2019-2020) (Mar. 12, 2019) (with Timothy J. Sloan, President and Chief Executive Officer of Wells Fargo \& Company, as sole witness).

151 For an account of how Wells Fargo managed the scandal fallout see Hilary F. Sisco, Financial Crisis Management and Wells Fargo: Reputation or Profit?, in THE HANDBOOK of FinANCIAL COMMUNiCATION AND INVESTOR RELATIONS 319 (Alexander V. Laskin ed., 2017).

152 See Hadfield-Menell \& Hadfield, supra note 142, at 421 (acknowledging that "alignment of artificially intelligent agents with human goals and values is a fundamental challenge in AI research.").

153 See LANGdon Winner, The Whale And the REACtor: A SEARCH FOR Limits IN an Age of High Technology 21-22 (1986). 
that algorithms can be non-conflicted or neutral are ill-founded: CorpTech solutions are bound to reflect the interests and views of those ultimately in control of the code selection and design process. If, as has hitherto been the case across corporations, management wields influence over the CorpTech system as a component of its IT system, ${ }^{154}$ then CorpTech solutions will reflect management's interests and views. If management's incentives are not perfectly aligned to those of their principals, then boards' (and shareholders') trust in the relevant CorpTech will be misplaced. ${ }^{155}$

The coders (perhaps with the help of their marketing departments if they are independent suppliers) will know who, within each corporation, is in charge of selecting them as code suppliers and directing their work. They will naturally make product choices that fit such buyers' interests. If managers are those making such purchasing decisions, then the CorpTech will further management's interests.

To illustrate this general point about conflicted coding, take the troublesome issue of managerial compensation. It has been debated whether this is an area where abuse and suboptimal bad practices are ripe, be it because CEO compensation packages are excessive or because prevailing compensation practices generate skewed incentives for managers. ${ }^{156}$ Contrary to the tech proponents' view, ${ }^{157}$ unless the analogic mechanics of

154 Chief Information (or Technology) Officers usually report to the CEO or the CFO: see e.g. Alexander Hütter \& René Riedl, Chief Information OfFicer Role EFFECTIVENESS. LiterATURE REVIEW AND IMPLICATIONS FOR RESEARCH AND PRACTICE 12 (2017).

155 In other words, the governance risk of CorpTech stems not only from "bad coding" in a technical sense, but also from the fact that code developed under management influence is bound to be skewed towards management's interests. See John Armour, Luca Enriques, Ariel Ezrachi \& John Vella, Putting Technology to Good Use for Society: The Role of Corporate, Competition and Tax Law, in 6 J. BRITISH ACAD. 285, 298 (2018) ("the incentives of the persons designing a firm's internal performance monitoring systems are likely to become even more significant").

156 Compare Lucian A. Bebchuk, Jesse M. Fried \& David I. Walker, Managerial Power and Rent Extraction in the Design of Executive Compensation, 69 U. CHI. L. REV. 751 passim (2002) (arguing that structural flaws in corporate governance have enabled managers to influence their own pay and extract rents to the detriment of shareholders) with Kevin J. Murphy, Explaining Executive Compensation: Managerial Power Versus the Perceived Cost of Stock Options, 69 U. CHI. L. REV. 847 passim (2002) (criticizing Bebchuk, Fried and Walker's theses) and Steven N. Kaplan, Are US CEOs Overpaid?, 22 ACAD. MGMT. PERSP. 5, 8-14 (2008) (criticizing the view that US CEOs are overpaid and not paid for performance).

157 As we have seen supra notes 41-43 and accompanying text, some have suggested that AI and Big Data may allow a company to consider all relevant information and possibly learn from other companies' best practices to devise the optimal compensation package, while smart contracts could make the compensation arrangement harder to alter in opportunistic ways further down the road. 
executive compensation setting are fixed, digital solutions will be insufficient. In fact, if the current system relying on compensation consultants selected by independent board committees and assisting the latter in their determinations is flawed, ${ }^{158}$ then there is little reason to believe that an algorithm will improve upon current practices: it will rather reflect any flaws arising from them. What it can achieve is the devising of the perfect compensation package that the existing compensation practices allow for: this is a different kind of perfect - perfect not in the sense of being optimal for shareholders, but in the sense of perfectly processing all information in the way that best caters to the interests of those who control the process.

\section{c. Information flows}

The biggest hindrance to a more balanced distribution of power between management, boards and shareholders in publicly held corporations is management's exclusive access to the inner workings of the corporate business and its ensuing filtering role as regards the information set that is needed to monitor its performance. ${ }^{159}$ Can IT solutions overcome such a hitherto inevitable corporate governance trait? So long as management retains control of the coding, data sources and algorithms used for reporting to a board, ${ }^{160}$ the answer is no.

Take again here the example of executive compensation. Optimal compensation packages are firm- and employee-specific. ${ }^{161}$ Coding optimal compensation models requires in-depth firm-specific, forward-looking information usually monopolized by management. If management is involved, it can be expected to use its superior knowledge to make sure that the code reflects its interests.

When an AI CorpTech product processes data, understanding the extent to which management manipulates a board by providing more or less data than necessary and whether the algorithm presents them in an unbiased

158 The jury, of course, is still out on whether executive compensation is more a solution to, or a manifestation of, managerial agency problems. For a recent discussion of the various facets of the problem see e.g. Guido Ferrarini \& Maria Cristina Ungureanu, Executive Remuneration, in THE OXFORD HANDBOOK OF CORPORATE LAW AND GOVERNANCE 334 passim (Jeffrey N. Gordon \& Wolf-Georg Ringe eds., 2018).

159 See e.g. EISENBERG, supra note 62, at 144 ("the amount, quality, and structure of the information that reaches the board is almost wholly within the control of the corporation's executives"). See also Bengt Holmlström, Pay without Performance and the Managerial Power Hypothesis: A Comment, 30 J. CORP. L. 703, 711 (2005) (highlighting how boards need to have the CEO's trust for the latter to be willing to share essential information about the company's with the former).

160 See discussion supra Section III.B.1.a.

161 See e.g. David I. Walker, Evolving Executive Equity Compensation and the Limits of Optimal Contracting, 64 VAND. L. REV. 609, 621-23 (2011). 
way is increasingly difficult. The risk of algo-supported board members becoming executives' puppets without the slightest suspicion of being manipulated may be even higher than for analogue boards. In fact, wellfunctioning analogue boards are trained to second-guess the completeness and reliability of the supporting information selected by the CEO. They may rely on their experience and on their instincts. In an algorithmic world, these instincts may prove less useful and it may be harder to question the completeness and reliability of information that a supposedly objective machine, rather than a self-interested human, has selected and processed.

\section{The Board Disintermediation Hypothesis}

Involvement in shareholder dialogue grants independent directors an important mediating role between shareholders and the company's management. The mediating role is premised on shareholder identification and shareholder intelligence: companies have to get to know their shareholders (something that DLTs will facilitate ${ }^{162}$ ). In addition, if companies are to secure shareholder backing, they also have to know their individual shareholders' preferences. Shareholder dialogue, finally, is more than simple information transmission (something at which CorpTech is particularly good): it can include the difficult task of persuading shareholders that something (apparently) at odds with their preferences should nevertheless be given support. In practice, this often involves various rounds of negotiations and requires-as we argue in this section-a significant degree of human judgment.

Tech proponents argue that CorpTech will change the (relatively new) mediating role of a board in two ways: first, it may enable shareholders to monitor management themselves, making the board's monitoring on their behalf obsolete. In a CorpTech-dominated environment where the costs of shareholder engagement, and voting in particular, are greatly reduced, direct shareholder-to-management relations may substitute for the present boardcentered governance framework. ${ }^{163}$ Second, CorpTech could make the mediating functions of non-executive members similarly passé, as the new information tools may allow shareholders to directly engage with management just as effectively.

In this section, we show that this board disintermediation hypothesis is flawed: it disregards inherent governance features which technology cannot cure and IT limitations.

162 See the examples supra notes 36-39 and accompanying text.

163 See supra Section II.A.2. 
1. Governance's inherent features

The board disintermediation hypothesis rests on two assumptions: first, that CorpTech allows for real-time accounting and "full transparency;" and, second, that CorpTech further reduces the cost of processing available information and deciding how to vote. The combination of the two should enable shareholders to do the monitoring board's job themselves. We do not question the technical possibility of processing and analyzing a virtually unlimited volume of information. And, incidentally, we leave apart the fact that DLTs reduce the risk of data manipulation but, of course, do not ensure that data stored via DLTs is correct. ${ }^{164} \mathrm{We}$ argue instead that the full transparency hypothesis is unrealistic and that, even if it was realistic, shareholder monitoring would still be patchy at best. We finally contend that shareholder dialogue exclusively involving executives, rather than directors, would lead to inferior outcomes.

a. Information asymmetries to persist

Corporations are engines of innovation. Shareholders delegate the power to conduct a company's business to a management team which has full control over the company's operations and resources under the board's oversight. Delegation is also needed to preserve confidentiality of a company's plans and strategies, which in turn is necessary for it to make profits. This is a simple fact that is ignored in the assumption that technology-enabled full transparency can be realized. ${ }^{165}$

Issuer disclosures, whether mandatory or voluntary, have become more frequent and richer ${ }^{166}$ and will become even more so in an AI-enhanced environment where the use of machines should make information overload less of a concern for policymakers. ${ }^{167}$ Yet, U.S. corporations can be particularly reticent when it comes to discussing one's plans, strategies, R\&D projects, and anything that may be of crucial interest to competitors. One example of that is Apple's protracted silence over its Apple Watch sales: while analysts agree that such sales figures would be extremely valuable

\footnotetext{
$164 \quad$ See e.g. Zetzsche, Buckley \& Arner, supra note 7, at 1374.

165 See e.g. Kevin S. Haeberle \& M. Todd Henderson, Making a Market for Corporate Disclosure, 35 YALE J. ON REG. 383, 391-92 (2018) (highlighting how sharing information about a firm's successes and failures may have a negative impact on its profitability).

166 See Gordon, supra note 62, at 1545-61.

167 See e.g. Troy A. Paredes, Blinded by the light: Information overload and its consequences for securities regulation, 81 WASH. U.L.Q. 417, passim (2003) (outlining the argument that too much information can be counterproductive).
} 
information for investors, ${ }^{168}$ U.S. securities regulation does not require Apple to disclose it and Apple's management has consistently refused to voluntarily provide the market with the relevant figures. ${ }^{169}$

Not only are corporate disclosures bound to remain patchy, but it is also highly unlikely that technology will prevent traders from concealing their trades, given the value secrecy entails for them. ${ }^{170}$ Tech proponents themselves acknowledge this and present the scenario of full trading and ownership transparency as just one option that may become available on the market for individual issuers to choose. ${ }^{171}$ However, even issuers most worried about hostile takeovers and activist campaigns will find an alltransparent trading environment unattractive, and prefer tools less harmful to their competitiveness to insulate themselves from hostile bidders and activists.

b. Passive and closet index funds: collective action problems to persist

Even in a world with lesser (or no) information asymmetry, the board disintermediation hypothesis disregards the real problem with informed voting: rational reticence. If a passive mutual fund invests in information in order to cast the right (shareholder-value maximizing) vote, it will improve a company's stock performance (assuming it is right), which means that freeriding competitors will gain more than the passive mutual fund does. ${ }^{172}$ Unless the costs of getting informed and voting become negligible, technology will not alter the incentive of passive institutional investors (and closet index funds ${ }^{173}$ ) to remain reticent. We expect reticence to be

168 See e.g. Don Reisinger, Here's How Popular Apple Watch Was Last Quarter, FORTUNE, Feb. 8, 2017, available at http://fortune.com/2017/02/08/apple-watch-2016-sales/ (reporting analysts' estimate of Apple Watch's sales during the fourth quarter of 2016).

$169 \quad$ Reisinger, supra note 168 (stating that "[w]hile Apple has said that its smartwatch is popular, the company has never revealed actual sales figures. Apple CEO Tim Cook has argued that sharing sales figures could help competitors."); See also Haeberle \& Henderson, supra note 165, at 392-94 (using the example of Apple's iPad sales to illustrate how disclosure thereof would lead to reduced cash-flows).

${ }_{170}$ Note that this argument is independent of technological progress; it will hold true even where data processing and storage capacity keep growing exponentially.

$171 \quad$ Yermack, supra note 41, at 18.

172 See Ronald J. Gilson \& Jeffrey N. Gordon, The Agency Costs of Agency Capitalism: Activist Investors and the Revaluation of Governance Rights, 113 COLUM. L. REV. 863, 867 (2013).

173 In addition to overtly passive index funds, a number of "closet index funds" exist that are marketed as actively managed funds but de facto replicate the composition of entire markets or segments thereof. See K.J. Martijn Cremers \& Quinn Curtis, Do Mutual Fund Investors Get What They Pay for: Securities Law and Closet Index Funds, 11 VA. L. \& Bus. REV. 31, especially at 46-67 (2016) (finding that ten percent of mutual fund assets can be categorized as closet index funds). 
particularly persistent given the increasing market share of passively managed mutual funds in the asset management market. ${ }^{174}$

Delegating the whole process of deciding how to vote to a machine would drive down the (marginal) costs of becoming informed and voting to close to zero: an algorithm would gather all available information, evaluate it according to a set of criteria and spit out a voting recommendation. That is what proxy advisors already do, albeit with a human touch. ${ }^{175}$ It is immediately clear, though, that developing proprietary software for these purposes would be too large an investment for an institution that mainly competes on management fees. Existing providers of proxy services are thus most likely to be the ones that will come up with such a product. Alternatively, perhaps asset management services providers, such as BlackRock, could develop this product as part of their management and administration analytics tools. ${ }^{176}$ BlackRock itself, though, is an unlikely supplier of such a product: were it also to provide the tools for determining other institutions' voting decisions, existing concerns about the disproportionate power of behemoth institutional investors and the anticompetitive effects of common ownership ${ }^{177}$ would substantially increase. The prospect of a negative political reaction would likely discourage BlackRock (or other large players in the asset management industry) from entering into the proxy advice and voting processing market.

Even if we assume, for the sake of argument, that one large investment house develops voting decisions algorithms, it is open to question whether an algorithm would, on average, do better at issuing voting recommendations than the staff of Institutional Shareholder Services or Glass Lewis, the two dominant proxy advisors today. ${ }^{178}$

In turn, if those designing and selling the software are the two proxy advisory firms themselves, as can reasonable be predicted, their product may avoid some human error. But it is far from clear that the relevant software

174 See e.g. Lucian A. Bebchuk \& Scott Hirst, Index Funds and the Future of Corporate Governance: Theory, Evidence, and Policy, 119 ColuM. L. REV. 2029, 2033 (2019).

175 See e.g. Paul H. Edelman, Randall S. Thomas \& Robert B. Thompson, Shareholder Voting in an Age of Intermediary Capitalism, 87 S. CAL. L. REV. 1359, 1398-99 (2014).

176 For a description of BlackRock's management and administration analytics tools suite, known as Aladdin, see Daniel Haberly et al., Asset Management as a Digital Platform

Industry: A Global Financial Network Perspective 17-18 (2018), http://dx.doi.org/10.2139/ssrn.3288514 (also quoting Larry Fink's dubbing of Aladdin as "the Android of finance").

$177 \quad$ See e.g. Einer Elhauge, Horizontal Shareholding, 129 HARV. L. REV. 1267 (2016) (outlining the antitrust perils of ownership of firms within the same industry by the same large institutions).

178 See e.g. Stephen J. Choi, Jill E. Fisch \& Marcel Kahan, The Power of Proxy Advisors: Myth or Reality?, 59 EMORY L. J. 869 passim (2010) (finding that ISS is the most influential proxy advisor, with Glass Lewis coming closely behind it). 
would succeed in overcoming the (apparent) deficiencies of today's proxy advisory services, which many characterize as box-ticking, one-size-fits-all exercises mirroring the majority views among institutional investor clients, ${ }^{179}$ which are themselves often laden with conflicts of interests. ${ }^{180}$ In theory, algorithms may be equally good at that, if not better, but it is hard to understand how they could do things in a different, more tailored and more granular way without obtaining specific input from the institutional investor client using it, which institutions other than the world's largest would find burdensome and hence competitively harmful. ${ }^{181}$

c. Active investing and shareholder activisim: less or more?

Rational reticence is not a problem for institutional investors that are overweighted on a given stock, as they own more shares in a company than the average (passive) investor. ${ }^{182}$ That is usually the case of (truly) ${ }^{183}$ actively managed funds and activist funds. ${ }^{184}$

Active traders and activist investors are in fact among the main participants in the dialogue between corporate boards and shareholders: active investors may respond to unexpected negative information by selling the corporate stock unless the company's ongoing dialogue with them has laid the foundations for good relations and trust long before difficulties emerge. Activist investors' demands, in turn, keep boards on their toes, requiring boards to assess the merits of such demands, attempt to persuade the activists that their demands are unjustified and/or secure support from other shareholders against the activists.

Tech proponents predict lower returns for both investor types because of the full transparency they envisage, which would reduce the likelihood of profiting from informational advantages. If both strategies became less

$179 \quad$ See id. at 883.

180 See Tao Li, Outsourcing Corporate Governance: Conflicts of Interest and Competition in the Proxy Advisory Industry, 64 MGMT. Sc. 2951, 2969 (2018).

181 Proxy advisors provide tailored services only to their largest clients. See Luca Enriques \& Alessandro Romano, Institutional Investor Voting Behavior: A Network Theory Perspective, 2019 U. ILL. L. REV. 223, 238. Machines could of course do the same, but the fact remains that they would either be developed by proxy advisors themselves or by the few giant institutions whose size would justify their (nontrivial) development costs.

182 See e.g. Bernard S. Black \& John C. Coffee Jr., Hail Britannia?: Institutional Investor Behavior under Limited Regulation, 92 MICH. L. REV. 1997, 2048 (1994) (noting that institutional investors are not necessarily passive when they "own[] a greater share of the specific company than [they] own[] of the market generally").

183 See supra note 173.

184 See e.g. Leo Strine, Who Bleeds When the Wolves Bite? A Flesh-and-Blood Perspective on Hedge Fund Activism and Our Strange Corporate Governance System, 126 YALE L.J. 1870, 1885-1910 (2017) (describing activist hedge funds and their governancerelated strategies). 
profitable, fewer investors of this kind are to be expected. That, in turn, should reduce the need for board mediation. ${ }^{185}$

For the sake of argument, let us leave aside the fact that the full transparency scenario is unrealistic. ${ }^{186}$ Even in a hypothetical full transparency scenario, it would follow from the Grossman-Stiglitz paradox that there would be room for active (informed) trading. ${ }^{187}$ Consider that even in a CorpTech world, information gathering and processing requires some investment. If share prices perfectly and constantly reflected all available information, those who spent resources to obtain information would receive no compensation, and hence would have no incentive to invest in information gathering and processing. Without active trading, however, prices would no longer reflect all available information, which in turn would make it profitable for active traders to come back to the market and push prices "back" to the levels justified by the available information.

We can go one step further, and argue that it is far from certain that less active investing would follow the widespread adoption of CorpTech. We can understand active investing as the outcome of an inequation with three values: information costs (I), trading costs $(\mathrm{T})$, and returns from trading $(\mathrm{R})$. If $\mathrm{R}-(\mathrm{I}+\mathrm{T})>0$, active investing will follow. Technology, by making big data analytics tools widely available, may indeed reduce profit opportunities from informed trading (resulting in a lower R). But at the same time, both information costs (I) and trading costs (T) would also go down: DLT (as a storage tool) and AI (as an analytical tool) will reduce information costs, while one of DLT's core applications will be clearing and settlement, implying lower trading costs. If, due to technology, I and $\mathrm{T}$ become lower than today, then more informed trading could result, even where $\mathrm{R}$ is lower than today. All in all, similar to the present world we expect an "equilibrium

185 See supra notes 79-82 and accompanying text.

186 See discussion supra Section III.C.2.a. It is easily conceded that AI is bound to lower profits from active trading, because it allows active investors to make better use of existing available information; it does so by unearthing patterns and highlighting correlations that help devise trading strategies and ideas and thereby enhance market efficiency. Share price efficiency itself yields greater managerial discipline, but, to a considerable extent, that is mediated by internal governance mechanisms such as boards (see Gordon, supra note 62, at 1541) and there is no intuitive reason to expect that a higher degree of market efficiency should make the current internal governance mechanisms redundant.

187 See Sanford J. Grossman \& Joseph Stiglitz, On the Impossibility of Informationally Efficient Markets, 70 AM. ECON. REV. 393 passim (1980) (arguing that a competitive equilibrium, "defined as a situation in which prices are such that all arbitrage profits are eliminated," is impossible "for then those who arbitrage make no (private) return from their (privately) costly activity. Hence, the assumptions that all markets, including that for information, are always in equilibrium and always perfectly arbitraged are inconsistent when arbitrage is costly"). 
degree of disequilibrium", ${ }^{188}$ with a varying degree of active trading -at times more, at times less - to continue.

This insight can be transferred to activist strategies. Activist strategies are the outcome of a similar inequation as above: if $\mathrm{R}-(\mathrm{I}+\mathrm{T}+\mathrm{E})>0$, activism will follow, ${ }^{189}$ where $\mathrm{I}$ and $\mathrm{T}$ are, again, information and trading costs, $\mathrm{E}$ stands for engagement costs and $\mathrm{R}$ for returns from activism. If $\mathrm{R}$, thanks to technology, were the only variable to fall, then the outcome would be less activism. However, DLTs, big data analytics and AI should reduce I and T. ${ }^{190}$ Hence, even a lower R may still generate profits.

The important point here is that, as long as there is any gain to be made from informed trading or activist strategies, with new technologies we may see more, rather than less, active trading, or activism, respectively. If this is the case, technology would make the need for a mediating institution like a board of directors even greater than it is today.

d. Shareholder dialogue with conflicted managers less fruitful

If dialogue with and among shareholders reverted to being mediated by managers, outcomes would be different, and arguably worse: to start with, some ideas presented by shareholders would not find fertile ground when presented to management. For instance, shareholders asking for the removal of the CEO, proposing a control sale, or pressing against a CEO's pet project that, in their view, destroys corporate value, will receive, at best, a lukewarm response when they contact the CEO. On the contrary, they might more easily sow the seeds of doubt when meeting independent directors. Their mediation, in turn, may reduce either the cost of implementing the change or the risk of escalation in case the company resists the appeal for change.

In addition, in the absence of board involvement, information flows among shareholders, as currently mediated to some degree by the companies' boards, may become less fluid. If shareholders fear that management is taking advantage of the views they share with it, they may be less inclined to air them, preventing the company from relaying such views to other shareholders. With less fluid communications among shareholders, the risk of polarization of views among shareholders would increase and, simultaneously, uncompromising, suboptimal positions would be more likely

\footnotetext{
$188 \quad I d$., at 393.

189 Cf. Brian R. Cheffins \& John Armour, The Past, Present, and Future of Shareholder Activism by Hedge Funds, 37 J. CoRP. L. 51, 61-62 (2011) (for a simple model for predicting when activists will engage with a given company).

190 While some phases of engagement could be automated (e.g. the initial contact with issuers on matters identified by applying big data analysis), the core of engagement activities cannot, given the social nature of the interactions involved; no meaningful reduction in $\mathrm{E}$ can therefore be expected. See infra text preceding note 191.
} 
to prevail.

\section{IT Limitations}

One could also imagine a world in which algorithms replace boards in their mediating functions. For such a scenario to be realistic, it would have to be the case that the relevant CorpTech is able to imitate the full variety of human behavior, in an effort to accommodate various parties with antagonistic views and to facilitate the emergence of value-creating solutions. That is highly unlikely to be the case. ${ }^{191}$

Technology experimenting with adjudication functions does exist ${ }^{192}$ but is limited to either non-complex adjudication tasks (including claims collection for traffic violations, paying/denying insurance and public benefits) or supervisory orders in time-sensitive situations (such as gas leaks, nuclear fall-outs and intervention in algo-based trading systems). ${ }^{193}$ Neither of these examples presents similarities with board-style mediation tasks.

To be sure, technology will make progress, and will possibly become able to manage complex social interactions: Google's virtual assistant scheduling barber appointments ${ }^{194}$ is one prototypical example, with many more certain to follow. In a distant future technology may entertain social interactions with humans. Nevertheless, the coding of mediating board functions will be particularly challenging: while technology may be particularly good at juggling a variety of conflicting interests (i.e. in data terms: variables), in corporate matters it is rarely certain which constituencies pursue which interests. At the beginning of controversial processes, all constituencies demand the maximum, use side demands to cloak their true

191 See Frey \& Osborne, supra note 20, at 262 (reporting the prediction that machines will be unable to replicate social intelligence tasks in "the next decade or two").

192 Note that algorithmic adjudication differs from algorithmic big data-driven legal predictions; the latter have been developed to reach an impressive degree of accuracy. See Daniel M. Katz, Quantitative Legal Prediction-or How I Learned to Stop Worrying and Start Preparing for the Data Driven Future of the Legal Services Industry, 62 EMORY L.J. 909, 928-47 (2013) (citing prediction results from e-discovery, securities litigation and U.S. Supreme Court cases).

193 See Cary Coglianese \& David Lehr, Regulating by Robot: Administrative DecisionMaking in the Machine-Learning Era, 105 GEO. L.J. 1147, 1167-75 (2017) (describing and giving examples for automated administrative decisionmaking in the U.S. context); Gregory Scopino, Do Automated Trading Systems Dream of Manipulating the Price of Futures Contracts?: Policing Markets for Improper Trading Practices by Algorithmic Robots, 67 FLA. L. REV. 221 passim (2015) (discussing digital supervision of trading systems).

194 See Press Release, Reuters Business News, Google Eases Tech Stress with App Controls, Table-Booking Assistant, May 8, 2018, https://www.reuters.com/article/usalphabet-developers-idUSKBN1I92ME. 
motives, or remain silent, according to the circumstances, in an effort to generate strategic advantages in negotiations.

Given AI CorpTech's dependency on data, ${ }^{195}$ where there is no (or in our case: no reliable) data to process, technology cannot help. Human board members spend significant time (through conversations and other forms of human interaction) on "fact-finding" and identifying crucial and less crucial interests, in an effort to pinpoint the crunch line for a brokered compromise among antagonistic shareholder groups and/or between management and the shareholder base. ${ }^{196}$ The real challenge lies in the dynamic nature of such interactions. Governance mediation takes place within a highly volatile system involving multiple actors, diverse interests and a firm's very future, which is, of course, uncertain. In short, this system is a complex one in the scientific meaning, that is, a system with "a significant number of interconnected parts that as a whole tend to interact in a nonlinear manner." 197 From a technological perspective: "[a]s the dynamics of the system being modeled become more volatile, so too do the predictions of that system's behavior." 198 In plain language, in such a setting, AI-driven predictions are random. Even assuming that constituencies are willing to accept a tech-driven process as superior to a human-brokered one, they are highly unlikely to accept random results.

\section{Intermediate Results: Utopia Reconsidered}

Based on what we know today about technology and corporate governance, the scenario of corporate board obsolescence is unrealistic. As we have shown in this Part, corporate governance challenges will persist even in a tech-dominated environment, so long as human beings wield influence over the firm's assets. As ever, corporate governance will ultimately be about who controls corporate assets and how much the interests of those in control deviate from those of the shareholders (and other constituencies, insomuch as corporate governance is instrumental in handling relationships with them as well). As a corollary, contrary to the tech proponents' view, technological changes are unlikely to trivialize the board's core monitoring and mediating functions.

195 See discussion supra Section III.B.1.a.

196 On the complex dynamics of negotiations with activists see e.g. Lucian A. Bebchuk, Alon Brav, Wei Jiang and Thomas Keusch, Dancing with Activists 5, 29, Harvard Law and Economics Discussion Paper No. 906 (2017), www.ssrn.com/abstract=2948869 (examining negotiations between issuers and activists and their outcome).

$197 \quad$ Katz, supra note 192, at 959.

$198 \quad I d$. at 953. 
Yet, in a CorpTech age the focal point of corporate governance conflicts will indeed change and is arguably changing already: ${ }^{199}$ the key question is becoming who controls the CorpTech within the firm. Decisions such as whether the firm develops its own algorithms internally and under which chain of command, which algorithms are licensed for which purpose, which data pool is analyzed, and so on, now affect the quality of a firm's governance as never before. If management is in control of those decisions, we expect it to choose coders and technology designs catering to its own interests, which may not be perfectly aligned with the interest of shareholders. On top comes the risk that, in the transition to a CorpTechdominated environment, insufficient understanding of the limits of CorpTech and over-confidence in their promise may even aggravate agency problems within firms.

Depending on how CorpTech governance itself is designed, the implementation of CorpTech solutions may cut both ways: it can be instrumental in either enhancing or reducing agency costs. Correspondingly, CorpTech is bound to either reinforce the board's monitoring role by improving the factual basis for human judgement-based decisions and the detection of compliance failures or weaken it by feeding directors with management-friendly analytical tools. The former will happen if humanpopulated boards exist that control the CorpTech choice and application, while the latter is likely if boards are replaced by, or disregard the risks associated with, CorpTech. To conclude, CorpTech by itself will not ensure better governance, but requires a governance framework ensuring that its benefits come to the fore, while associated risks are under control.

This conclusion holds with one important caveat: if predictions, as per the old saw, are difficult especially about the future, predictions about technological innovation and its impact are even harder to make. At some point in the distant future, CorpTech may become so sophisticated as to be able to keep management under control better than humans. If and when that will be the case, however, no one can tell precisely.

\section{A GOVERNANCE FrAMEWORK FOR THE CORPTECH AGE}

What are the elements of the governance framework that will ensure CorpTech's beneficial impact? In the following sections we lay out some policy considerations and provide tentative ideas on how to shape board governance in the CorpTech age.

See supra Section III.B.2.b. 


\section{A. Product Market Competition?}

A focus on CorpTech governance is only justified if market mechanisms do not already ensure that CorpTech serves shareholders' interests. In fact, one could counter that the natural solution to the new tech-centered dimension of intracorporate conflicts of interest is the market itself, that is, competition among suppliers of CorpTech products. ${ }^{200}$ This section casts doubt on the idea that product market competition can be sufficient to let us stop worrying and unreservedly embrace CorpTech.

First of all, there are reasons to be skeptical about the likelihood of the market for CorpTech solutions delivering products that are genuinely in line with the interests of shareholders. For one, product market competition works only where a sufficient number of suppliers of CorpTech systems offer services, struggling for clients' attention through innovation and product differentiation. With the sector still being in its infancy, it is pure speculation whether one, two or a handful of CorpTech providers will survive in the medium to long term. Yet, if past trends are of any guidance, time and again long-term software market dynamics yield a small number of dominant IT platforms. ${ }^{201}$ Given the network effects and economies of scale inherent in data-driven applications, which increase switching costs and entry barriers, ${ }^{202}$ a different equilibrium is unlikely in the CorpTech market.

To be sure, even in a market dominated by a few firms, one or more among them may start competing by building a pro-shareholder brand. Corporations' use of CorpTech products with a pro-shareholder reputation could bring some gains in the form of higher stock prices for their users.

Consider, though, that a brand-building strategy is much more likely to pay off for standardized software tools than for tailored, firm-specific ones. In fact, the more firm-specific the CorpTech, the less credible the proshareholder signal sent by choosing a given CorpTech application. That is because management input for the development of the tailored code will be key. Correspondingly, the greater the coder's specific investments in the relationship with an individual company, the weaker the signal of

See Bamberger, supra note 16, at 713 (arguing in favor of diversification of risk management systems to counter implicit biases).

201 Tim Wu, The Master Switch: The Rise and Fall of Information EMPires (2010) (arguing that information markets tend to turn into monopolies until they are replaced by superior technology). See also Lina M. Khan, Amazon's Antitrust Paradox, 126 YAlE L.J. 564 (2017) (detailing how traditional antitrust law interpretation furthers the build-up of monopolies in platform markets); Aghion et al., supra note 60, at 32-33 (arguing that data access may act as an entry barrier for creating competing networks, hence the incumbent's platform prevails).

202 See Khan, supra note 201, at 772-73 and 785-86. 
independence. For this reason, a brand-building strategy is unlikely to work wherever the CorpTech's added value comes from customization, as is arguably the case with most CorpTech applications. In fact, no two firms are alike; software developed for one firm will not work so well for others.

In addition, similar to what has traditionally happened with audit firms and other gatekeepers, unless the governance of a firm's (and its management's) relationship with the supplier is effectively taken care of, there is a risk of collusion with managers, that is, a risk of deviation ex post from shareholders' interests. ${ }^{203}$ Developing a reputation for producing good (i.e. shareholder-friendly) CorpTech would arguably be even harder than developing a reputation for providing good audit services, if only because there are, to date, no generally accepted coding standards that outsiders could use to understand what the coders have done. In addition, outside monitoring and review of algorithms is problematic. ${ }^{204}$

The contractual governance point can be generalized to cast doubt on the ailing effects of product market discipline: competitors will have to sell products that the relevant decision-makers within corporations will find attractive. Unless such decision-makers' incentives are fully aligned with the interests of shareholders, there is scope for suboptimal products to prevail on the market. But if full alignment is ensured, there will be no need for CorpTech.

\section{B. Best Practices: Expanding the Board Committees' Remit to CorpTech Oversight}

Information technology has traditionally been outside the board of directors' remit: the selection and management of technological solutions has rather been, and still is, part of the executives' domain. ${ }^{205}$ Banks represent an

203 See generally JOHN C. COFFEE JR., GATEKEEPERS: THE Professions AND CORPORATE GOVERNANCE 15-47 (2006) (describing the failure of gatekeepers and their collusion with management in the early 2000 s corporate scandals).

204 See Joshua A. Kroll et al., Accountable Algorithms, 165 U. PA. L. REV. 633 passim (2017) (arguing that research on AI review is in its infancy and that disclosure of results does not allow review of the underlying algorithm). See also Pauline T. Kim, Auditing Algorithms for Discrimination, 166 U. PA. L. REV. ONLINE 189 (2017) (arguing that code review does not result in desirable outcomes since the biases lie in broader social processes that cannot be countered by reviewing the code alone, but asking for code disclosure to let the public review the code outcome).

205 See HÜTTER \& RIEDL, supra note 154, at 11-12 (stating the CIOs either belong to the top management team or a department reporting to top management); see also Sid L. Huff, P. Michael Maher, Malcom C. Munro, Information Technology and the Board of Directors: Is There an IT Attention Deficit?, 5 MIS QuART. EXECUTIVE, Issue No. 2, 55 
important exception here: with the ever-growing use of algorithms in risk management, banks increasingly ask their risk committees to review technology-related risks. ${ }^{206}$

But even in non-financial corporations, where technology has typically been part of the oversight functions of the compliance or audit committee, ${ }^{207}$ things are changing fast. With technology taking center stage both as a managerial and a governance tool, and with boards currently being composed mainly of individuals often lacking the competence to understand such aspects, ${ }^{208}$ more systematic oversight of technology on the part a(n independent) risk or audit committee is becoming more common. ${ }^{209}$

Importantly, the practice of having tech committees, sometimes separate from risk management committees, sometimes as joint risk and technology committees, is spreading out, ${ }^{210}$ with cyber-attacks and

passim (2006) (stating that boards are focused on IT risks only and that only half of the financial firms and none of the non-financial firms surveyed discuss regularly IT issues other than IT risks, and also arguing that discussing the CIO's IT vision for the company, the IT strategic plan, major IT application decisions, IT leadership, IT functional structure, IT function effectiveness, and whether or not IT applications provide competitive advantage deserve board attention).

206 See Lawrence Trautman \& Kara Altenbaumer-Price, The Board's Responsibility for Information Technology Governance, 29 J. MARSHALL J COMPUTER \& INFO. L. 313, 319 (2011). Morgan Stanley has introduced a technology committee in 2015 that advises the board and management team on Big Data tools and systems that control stock trading. See Kim S. Nash, Morgan Stanley Board Pushes Emerging Area of Tech Governance, WALL ST. J., Mar. 26, 2015, https://blogs.wsj.com/cio/2015/03/26/morgan-stanley-board-pushesemerging-area-of-tech-governance/. Tech advisory boards are becoming common outside the banking sector as well. See e.g. Josh King, The Growth of Digital Advisory Boards (2016), https://www.linkedin.com/pulse/growth-digital-advisory-boards-josh-king/ ("All types of firms, from start-ups and growth companies to Fortune 500 businesses and even PE/advisory firms, are developing these advisory boards").

207 Richard Nolan \& F. Warren McFarlan, Information Technology and the Board of Directors, 83 HARV. Bus. REV., no. 10, 2005, at 96, 101.

208 Elizabeth Valentine \& Glenn Stewart, Director Competencies for Effective Enterprise Technology Governance, Proceedings of the 24th Australasian Conference on Information Systems (ACIS 2013), RMIT University, Melbourne, https://eprints.qut.edu.au/63374/ (at 5) (highlighting the need for boards to provide enterprise technology governance oversight of technology-related strategy, investment and risk, and to be competent in doing so, and arguing that "the gaps are large between the stated importance of business technology, actual board involvement ... [and] knowledge and experience to effectively oversee technology strategy.”). See also MCKINSEY \& Co., supra note 117, at 48 (arguing that approximately $45 \%$ of directors claim to have neutral or no competence on digitization, $49 \%$ on disruptive business models, and approximately $60 \%$ on cybersecurity). $209 \quad$ See Trautman \& Altenbaumer-Price, supra note 206, at 319.

210 See Bankewitz et al., supra note 19, at 65 (reporting that as of 2011, special board committees dealing with tech and cybersecurity were in place in less than twenty-five percent of organizations and expecting that the "changing board agenda based on the shifts in 
technology-related operational risk representing their core focus on the technology side. ${ }^{211}$ To the best of our knowledge, however, tech committees are not in the business of monitoring the conflicts of interest inherent to CorpTech governance. $^{212}$

An extension of tech committees' remit (or the remit of other board committees with the necessary tech knowledge in the ranks) to include CorpTech governance/oversight would seem to be a natural evolution in a tech-augmented governance framework: ${ }^{213}$ their extended focus should be on monitoring contract negotiations with coders, designing the governance of the contractual relationship with the coders, the review of the design settings of crucial algorithms as well as, possibly, a say on (internal) coders' compensation.

As with any governance tool, a board committee in charge of CorpTech oversight would be no silver bullet itself. Again, we can distinguish between technological limitations and governance's inherent traits. One considerable challenge in terms of technological limitations is that, at least at the current stage of IT development, ex post review of the functions, limits and biases of an algorithm is of limited effectiveness. ${ }^{214}$ Moreover, while independent directors themselves can work better than shareholders as monitors of management, including in overseeing management's exercise of discretion when it comes to CorpTech, they are bound to suffer themselves from information asymmetries and the imperfect alignment of incentives. ${ }^{215}$

organizational threats and opportunities may as well affect the committee structure of an organization," resulting in a greater role for, and wider diffusion of, tech committees).

$211 \quad I d$. at 65 (arguing that the "[m]ain tasks of such a [tech] committee may be for instance to ratify that information systems architecture will support the strategies of the company to validate the effective use of data security tools to evaluate data breach response plans and to oversight the managements' abilities to execute them."); see also Julia L. Higgs, Robert E. Pinsker, Thomas J. Smith \& George R. Young, The Relationship Between BoardLevel Technology Committees and Reported Security Breaches 30 J. INFORMATION SYsTEMS, no. 3, 2016, 79, 79-83 (arguing that tech committees are understood as part of the firm's information technology governance to signal the firm's ability to detect and respond to security breaches).

212 See Martin Lipton, Spotlight on Boards (Dec. 3, 2018), Harv. L. School Forum on Corporate Governance \& Fin. Reg., https://corpgov.law.harvard.edu/2018/12/01/spotlighton-boards-2/: while this client alert memorandum refers to oversight of technological risks as one of the items boards are expected to focus on in 2019 (id. at 1), oversight of CorpTech solutions is conspicuous by its absence.

213 See Armour \& Eidenmüller, supra note 18, at 21 (similarly suggesting the setup of a committee of independent directors in charge of "data governance").

$214 \quad$ See supra note 204 (and accompanying text).

215 See generally Stephen M. Bainbridge, The Board of Directors, in THE OXFORD HANDBOOK OF CORPORATE LAW AND GOVERNANCE, supra note 158, 275, at 316-20, 327- 
As a corollary, putting an independent (tech) committee in charge of selecting CorpTech may sacrifice business efficiency in the name of conflict monitoring. In fact, in modern corporations, business operations depend on the efficiency of systems, while such efficiency depends, in turn, on accuracy as to process details. Meanwhile, given the elusive boundaries between CorpTech and operations IT, ${ }^{216}$ putting an independent (tech) committee in between management and tech deployment could slow down information transfer from management to coders. Strengthening an independent (tech) committee oversight — rather than replacing management in the task—seems to be a balanced solution.

\section{The Case Against CorpTech Regulation}

Does the prospectively pervasive role of CorpTech in listed companies' governance warrant any changes in the statutory law (state or federal) of corporations?

We are hesitant to suggest so (with one exception laid out at the end of this Part, namely enhanced CorpTech governance disclosure). The main reason behind being cautious and recommending a wait-and-see approach is that corporate governance practices are bound to change in the direction of sharpening the focus on CorpTech issues. ${ }^{217}$ It would be premature, and contrary to a long-standing tradition in corporate governance reforms, to implement corporate governance-focused changes in state corporate statutes, federal securities regulation or stock exchange listing rules before best practices have emerged on the market. Furthermore, corporate governance practices are firm-specific. Firms differ, for instance, in the extent to which they rely on their employees' creativity, suppliers' tailored inputs, intellectual property, and technology integration among other factors. The downside of any prescriptive rule would be the risk of freezing much-needed experimentation in this area.

This is particularly true for a CorpTech licensing regime: ${ }^{218}$ any licensing regime potentially limits innovation since innovators would focus on the development of permissible products only. Besides general concerns

31 (describing independent directors' time constraints, limited access to the relevant firm's inside information, and skewed incentives, even after they started being given stock-based compensation, and summarizing the available empirical evidence).

$216 \quad$ See supra text following note 11.

217 See supra section IV.2.

218 As an indirect way of licensing, regulators could demand a liability insurance as a precondition for doing business where technology takes most business decisions such as in self-driving corporations or algorithmic entities. See Armour \& Eidenmüller, supra note 18, at 33 (proposing a mandatory liability insurance for "self-driving corporations"). 
aired against public tech oversight, ${ }^{219}$ a licensing regime also raises the perennial issue of who would enforce these rules. If authorization is in public hands, we would expect supervisory expertise and resources to be limited, resulting in slow-motion supervision, while potential liability and the risk of reputational loss may skew incentives towards a timid, anti-innovative supervisory approach. ${ }^{20}$ Novel regulatory approaches, such as regulatory sandboxes, special charters and innovation hubs, ${ }^{221}$ would deliver minor relief for CorpTech supervision: these instruments assist where the core issue is both the innovators' and supervisors' shortage of expertise, time and resources by both providing a temporary safe space for examining the impact of an invention under almost-real time conditions, and determining the adequate supervisory response. A sandbox approach for CorpTech, however, would provide little comfort for shareholders: it is far from clear that algorithms would show their true face in a sandbox. ${ }^{222}$ And, of course, the "learning" in machine learning does not stop with the final moment in the sandbox: any assessment achieved during the sandbox period would soon be outdated.

If authorization is put, by way of indirect supervision, in private hands, we are facing the question of "who watches the watchers?". This question has been long and widely discussed, and rarely answered convincingly, in the similar context of auditors and rating agencies. ${ }^{223}$ Second, CorpTech licensing is compounded by an additional layer of IT complexity, turning IT audit into an emerging science. ${ }^{224}$ The difficulties

219 See Julie E. Cohen, The Regulatory State in the Information Age, 17 THEORETICAL INQUIRIES L. 369, 370-71 (2016) (stating that it has become difficult to define "what constitutes 'normal' economic activity and what qualifies as actual or potential harm" for society, firms and its shareholders and stakeholders.").

$220 \quad C f$. Chris Brummer \& Yesha Yadav, Fintech and the Innovation Trilemma, 107 GEO. L.J. 235, 248-49 (2019) (arguing that innovation poses a challenge for regulators since regulators are expected to warrant financial innovation, simple rules and market integrity at the same time, with limited resources).

221 See Steven van Uytsel, Artifical Intelligence and Collusion: A Literature Overview, in Robotics, AI AND THE Future OF LAw 155, 175-177 (Marcelo Corrales, Mark Fenwick \& Nikolaus Forgó eds., 2018) (discussing testing of colluding algorithms in a sandbox).

222 See Ariel EzRachi \& Maurice Stucke, Virtual Competition: The Promise AND PERILS OF THE ALGORITHM-DRIVEN ECONOMY 230-31 (2016) (arguing with respect to competition law that sandbox test results finding collusion and non-collusion of algorithms are notoriously unreliable).

223 See e.g. JOHn C. COFFEe JR., GATEKeEPers: The Professions And Corporate GOVERNANCE 15-47 (2006) (describing the failure of gatekeepers and their collusion with management in the early 2000 s corporate scandals).

224 See Christian Sandvig, Kevin Hamilton, Karrie Karahalios \& Cedric Langbort, Auditing Algorithms: Research Methods for Detecting Discrimination on Internet Platforms 6-10, in Data and Discrimination: Converting Critical Concerns into Productive: A 
with code review are particularly pronounced for advanced machine-learning algorithms that receive feedback from non-human sources, for instance the price data feeds from stock and other markets. To our knowledge, technical means to review the function and limitations of self-learning algorithms do not yet exist. ${ }^{225}$

\section{Enhancing CorpTech-related Disclosures}

Instead of product regulation, policymakers could require the disclosure of the CorpTech code. The case for disclosure would rest on the assumption that knowledgeable shareholders, market analysts and traders would analyze the disclosures and trade on the basis of their analysis until the share price fully reflects the implications of those disclosures relative to the company's profitability. ${ }^{226}$ Anticipating market scrutiny, management would have an incentive to choose good software. Applying this logic, external IT experts, whether individually or as a group, could undertake such code reviews on an experimental basis. The more experiments of this kind that are undertaken, the greater the likelihood of imperfect CorpTech solutions being exposed as such. In fact, in IT circles, crowdsourced testing has been acknowledged as a powerful analytical tool for detecting code deficiencies. ${ }^{227}$

However, code disclosure will likely stifle innovation since it facilitates, if not encourages, the copying of the code; less investment in code development would follow. Furthermore, code disclosure is of no use where

Preconference at the 64th Annual Meeting of the International Communication Association, Seattle, WA (May 22, 2014) (providing an overview of audit methods, and outlining their deficiencies).

$225 \quad$ See supra note 204 (and accompanying text). Code reviews are limited to experiments where certain data feeds are provided to the algorithm, and the algorithm's output is assessed. But these experiments are by no means complete, nor can those experiments mimic real life conditions for enterprise software, especially if the exercise is undertaken without access to all the firm's and market data that feeds into the software. In order to control risks stemming from the self-learning dimension of algorithms, IT coders tend to limit the data access and processing functions of self-learning algorithms, thereby weakening one of the competitive advantages of CorpTech vis-à-vis humans, which is that those algorithms consider all available data and correlations.

$226 \quad$ See generally Zohar Goshen \& Gideon Parchomovsky, The Essential Role of Securities Regulation, 55 DuKE L.J. 711 (2005).

227 See Niklas Leicht, Ivo Blohm \& Jan M. Leimeister, Leveraging the Power of the Crowd for Software Testing, 34 IEEE SOFTWARE, no. 2, 2017, 62, 62-63 (arguing that crowdsourced testing replaces manual testing since manual testing is becoming less economically viable and useful). 
little, if any, firm-specific data is available to crowd testers. ${ }^{228}$ Firms will not voluntarily disclose the data they process in algorithms, as disclosure may harm their competitiveness and contravene confidentiality duties and data privacy.

Given the increasing centrality of tech issues for corporate governance, one contiguous area where a change in the law would help is the disclosure of listed companies' tech governance arrangements. Like similar disclosures, for instance on internal controls and executive compensation, ${ }^{229}$ the dissemination of information about individual companies' practices with regard to CorpTech oversight may help issuers become aware of better practices and further their adoption. The need to articulate CorpTech governance arrangements in disclosure documents, not to mention the risk of securities regulation regarding their contents, would also provide directors with the incentives to adopt appropriate CorpTech governance arrangements. ${ }^{230}$ Where disclosure shows that management and boards are lagging behind, shareholders-possibly assisted by CorpTech that monitors tech-related disclosures-may press for improvements.

Existing periodic disclosures on corporate governance arrangements could thus be supplemented with additional explanations on, for instance, whether the issuer has a tech committee (or whether one of the other existing committees have CorpTech oversight functions), whether any of the board members are tech experts, how compensation for the coders are determined, how the board oversees code design, development and upgrading, whether the board regularly engages in the review of existing IT structure, and so on. This could be either part of Securities and Exchange Commissions's annual disclosures $^{231}$ or of the New York Stock Exchange's Listing Rules' corporate governance-related disclosures. ${ }^{232}$

228 Any more limited disclosure allows management to argue that the deficiencies that the shareholders' and/or IT expert groups' analysis may reveal are due to "wrong" data used for the test or an incomplete embedding of the test software into the firm's operating system. $229 \quad$ See Items 407(d) and 407(e), Regulation S-K (17 C.F.R. § 229.407) (requiring disclosures, respectively, on audit committee composition, tasks and activities and on compensation committee, composition, tasks and functioning).

230 See generally Robert B. Thompson \& Hillary A. Sale, Securities Fraud as Corporate Governance: Reflections upon Federalism, 56 VAND. L. REV. 859, 909 (2003) (highlighting the role of mandatory disclosures in ensuring that directors fulfil their duty of care). We are grateful to Christopher Bruner for drawing our attention to this point.

231 See Item 407, Regulation S-K (17 C.F.R. § 229.407) (requiring disclosure on a number of corporate governance arrangements).

232 See NYSE Listed Company Manual § 303A.09 (2009) (requiring companies to have and disclose corporate governance guidelines and listing the items to be included therein). 


\section{CONCLUSION}

CorpTech is bound to have a significant impact on how corporate boards perform their functions: new technologies will in fact enhance them by improving the information collection and processing tools available to them. Yet, we have shown in this article that "Will CorpTech replace boards?" is the wrong question. ${ }^{233}$ CorpTech will not significantly change what boards do, namely monitoring managers and mediating between them and the company's shareholders and other stakeholders, because technology will not by itself solve the core corporate agency problems. The core insight of this article is in fact that corporate agency problems cannot be "coded away:" those in control of the CorpTech will (continue to) control the corporation and therefore preserve their ability to engage in self-serving behavior.

As building blocks of a governance framework for the CorpTech Age, we propose to tackle CorpTech manifestations of governance issues through rather traditional means, namely CorpTech board committees and disclosure of tech governance arrangements. These old-style, "analogue" tools, imperfect as they may be, can reduce the risk that CorpTech exacerbates corporate governance issues by making it even easier for managers to pursue their own agenda. Only if and when humans relinquish corporate control to machines, may the problems at the core of corporate governance be solved; but by then humans will have more pressing issues to worry about than corporate governance.

233 Cf. Curtis P. Langlotz, Will Artificial Intelligence Replace Radiologists?, 1 RADIOLOGY: ARTIFICIAL INTELLIGENCE, no. 3, 2019, at 1, 2 (“Will AI replace radiologists?' is the wrong question. The right answer is: Radiologists who use AI will replace radiologists who don't."). In the business context, see Ajay Agrawal, Joshua S. Gans \& Avi Goldfarb, What to Expect from Artificial Intelligence, MIT Sloan MgM't ReV. Digital 7 (2017), http://mitsmr.com/2jZdf1Y (expecting that "[i]ncreasingly, the role of the manager will involve determining how best to apply artificial intelligence. [...] Managing in this context will require judgment both in identifying and applying the most useful predictions, and in being able to weigh the relative costs of different types of errors.") 


\section{about ECGI}

The European Corporate Governance Institute has been established to improve corporate governance through fostering independent scientific research and related activities.

The ECGI will produce and disseminate high quality research while remaining close to the concerns and interests of corporate, financial and public policy makers. It will draw on the expertise of scholars from numerous countries and bring together a critical mass of expertise and interest to bear on this important subject.

The views expressed in this working paper are those of the authors, not those of the ECGI or its members. 


\section{ECGI Working Paper Series in Law}

\section{Editorial Board}

Editor

Consulting Editors

Editorial Assistant
Amir Licht, Professor of Law, Radzyner Law School, Interdisciplinary Center Herzliya

Horst Eidenmüller, Freshfields Professor of Commercial Law, University of Oxford

Martin Gelter, Professor of Law, Fordham University School of Law

Geneviève Helleringer, Professor of Law, ESSEC Business

School and Oxford Law Faculty

Curtis Milhaupt, Professor of Law, Stanford Law School

Niamh Moloney, Professor of Law, Department of Law, London

School of Economics and Political Science

Úna Daly, ECGI Working Paper Series Manager 


\section{Electronic Access to the Working Paper Series}

The full set of ECGI working papers can be accessed through the Institute's Web-site (https://ecgi.global/content/working-papers) or SSRN:

Finance Paper Series http://www.ssrn.com/link/ECGI-Fin.html

Law Paper Series http://www.ssrn.com/link/ECGI-Law.html 